\title{
Anmeldelser
}

\section{Erich Hoffmann:}

\section{Die Herkunft des Bürgertums in den Städten des Herzogtums Schleswig, 1953}

(Quellen und Forschungen zur Geschichte Schleswig-Holsteins bd. 27)

I årene efter 1933 tog den slesvig-holstenske historieforskning med stor energi fat på at udarbejde og udgive borgerbøger fra de slesvigske byer. Ludwig Andresen udgav i 1937 Bürger- und Einwohnerbuch der Stadt Tondern bis 1869, Th. O. Achelis Bürgerbuch der Stadt Hadersleben bis zum Jahre 1864 I i 1940, og man forberedte udgivelsen af borgerbøger fra Åbenrå og Sønderborg. I Sydslesvig opstillede dr. Schütt og Ernst Petersen lister over de nye borgere i Flensborg og Slesvig. Efter 1945 er arbejdet med byernes befolkningshistorie blevet fortsat, og Erich Hoffmann har nu i sin bog om det slesvigske borgerskabs oprindelse givet en samlet oversigt over udviklingen indtil 1750 .

Hans fremstilling bygger først og fremmest på fortegnelser over aflagte borgereder, enten de nu findes i særlige protokoller, i retsbøger, i rådsprotokoller eller kæmnerregnskaber. Fra den ældre tid mangler dette materiale dog, og i flere byer svigter det også helt eller delvis i nyere tid, men Hoffmann har prøvet at danne sig et begreb om borgernes nationale sammensætning på grundlag af de borgernavne, der findes i skattelister og lignende materiale. I visse tilfælde giver efternavnene oplysning om det sted, hvorfra manden eller hans slægt i sin tid er kommet, men som regel er det kun navnets karakter, der angiver, om den pågældende er af dansk, tysk eller frisisk afstamning. Selvom resultaterne af sådanne undersøgelser må vurderes med den største forsigtighed, er der dog ingen tvivl om, at de giver hovedlinierne i udviklingen. De viser, at der gennem tiderne har fundet en ret stærk indvandring sted til en del af de slesvigske byer, forst og fremmest til de sydslesvigske, og at Tonning, Eckernførde og Frederiksstad har haft et næsten helt tysk borgerskab, hvad der iøvrigt ikke er nogen overraskelse. Undersø- 
gelser af Sach og af danske forskere ${ }^{1}$ ) har for længst klargjort, at det tyske borgerskab i Slesvig var $i$ overvægt $i$ begyndelsen af 1400-årene. Hoffmann giver et mere nuanceret billede af udviklingen i denne by, end man før har kendt, og hans tal tyder på, at det danske islæt $i$ befolkningen har været i tilbagegang i slutningen af middelalderen, men var stigende efter 1500 uden dog nogensinde at nå op over 25 pct. I et register fra 1601 var 24,1 pct. af navnene danske, men derefter fandt der påny en nedgang sted.

Flensborg er jo den nationalt set interessanteste by i Slesvig, men da der foreligger omfattende danske undersøgelser over borgerskabets afstamning, ${ }^{2}$ ) er der ingen grund til at komme nærmere ind herpå. Det kan dog næevnes, at der fandt en del tysk indvandring sted både i middelalderen, i 1500-årene og begyndelsen af 1600årene, men at der synes at have været en tilbagegang efter 1640 . Derimod var indvandringen fra kongeriget i stadig stigen efter denne tid og nåede $\mathrm{i}$ årene $1720-50$ op på lige ved 17 pct. Mærkeligt nok kom der flere borgere fra øerne end fra Jylland til Flensborg. Det hænger uden tvivl sammen med den nære økonomiske forbindelse med kongeriget, ikke mindst med København, men skyldes også, at mange af de indvandrede jyder aldrig nåede op i borgernes rækker. Iøvrigt fik den jyske indvandring aldrig den samme betydning i Flensborg som i de nordslesvigske byer.

En væsentlig del af materialet fra Haderslev og Tonder er udgivet i de to nævnte værker af Andresen og Achelis, der også indeholder en statistisk bearbejdelse af stoffet. Fra Tønder findes desuden en dansk behandling i værket Tønder gennem Tiderne. Det sønderborgske materiale er ualmindelig dårligt, idet oversigter over de nye borgere først begynder 1831, og der bortset fra et skatteregister fra 1585 - mangler æeldre fortegnelser over skatteborgerne. Hoffmann mener ved en undersøgelse af dette at kunne fastslå, at navnene viser, at 18,5 pct. har været af tysk "Volkstum", 45,8 pct. af dansk, 2,2 pct. af frisisk og 33,5 pct. af uvis afstamning. En gennemgang af materialet, som jeg har foretaget, giver dog et noget andet billede, nemlig 9,7 pct. tyske, 1,5 pct. frisiske, 46,4 pct. danske og 42,4 pct. uvisse, altså et betydeligt mindre tysk islæt end efter Hoffmanns beregning. Af de 136 usikre var 41 sen-navne, 61 bestod af erhvervsbetegnelse og et fornavn, der både kan være tysk og dansk. En af grundene til uoverensstemmelsen i de to beregninger er sikkert, at Hoffmann ikke i tilstrækkelig høj grad har gjort sig klart, at en del tyske navne som Markvard, Claus

1) Se Sdj. årb. 1950 s. 196 og der anført litteratur.

2) Troels Fink i Til Knud Fabricius (1945) s. 13, Johan Hvidtfeldt og Age Bonde i Flensborg bys Historie I-II (1953-55). 
og Henrik allerede i middelalderen er blevet ret almindelige i kongeriget eller i hvert fald i den danske del af Slesvig, og at man derfor ikke kan henregne disse til de tyske navne, med mindre der er klart indicium for, at der virkelig er tale om folk fra det fremmede.

Fra Åbenrå er der et betydeligt større materiale, dels forskellige indbyggerfortegnelser fra 1609, 1625, 1674 og 1711, dels indførsler om aflagt borgered $i$ rådets forhandlingsprotokoller, nogenlunde fuldstændige fra $1723 .{ }^{1}$ ) Hoffmann har dog overset, at der findes et stolestaderegister fra $\left.1567,,^{2}\right)$ der indeholder 144 mandsnavne. Fordelingen af navnene $i$ dette og $i$ de fire af Hoffmann bearbejdede lister er således:

$\begin{array}{lrrrrrr} & & 1567 & 1609 & 1625 & 1674 & 1711 \\ \text { Tysk } & \ldots \ldots \ldots & 2,8 & 12,6 & 11,7 & 11,6 & 16,0 \\ \text { dansk } & \ldots \ldots \ldots & 59,8 & 54,8 & 49,5 & 45,1 & 47,7 \\ \text { frisisk } & \ldots \ldots & 3,5 & 4,0 & 2,4 & 7,4 & 5,7 \\ \text { usikker } & \ldots \ldots & 34,0 & 28,4 & 36,2 & 33,9 & 30,5\end{array}$

Mest bemærkelsesværdigt er den store forskel i det tyske islæet $\mathrm{i}$ befolkningen. Det er yderst usandsynligt, at den udelukkende skyldes en særlig stærk indvandring $i$ tiden 1567-1609, mere nærliggende er det, at Hoffmann og jeg har bedømt navnenes nationale oprindelse på forskellig måde. Ejendommelig er også stigningen af det tyske indslag $\mathrm{i}$ befolkningen $\mathrm{i}$ den sidste liste. Da man må gå ud fra, at forfatteren ved bearbejdelsen af de forskellige lister har fulgt de samme retningslinier, må det enten skyldes, at der har været en stigende tysk indvandring, eller at de tyske navne fra tidligere slægtsleds indvandrede mere og mere slår igennem.

I en samlet opgørelse over samtlige nye borgere i Åbenrå 1721-50 mener Hoffmann at kunne fastslå, at 15 pct. har været af tysk "Volkstum", 44,7 af dansk, 1,5 af frisisk, 15,9 af blandet, mens 20,4 er af usikker herkomst. Ser man bort fra de usikre, bliver det tyskfrisiske indslag $\mathrm{i}$ befolkningen 20,9 pct. Disse tal bygger på hjemstedsangivelserne, der findes ved knap halvdelen af borgerne, desuden på navnenes oplysning om, hvor familien oprindelig kommer fra (Herkunftsnamen) og på en vurdering af navnenes nationale karakter. Der er i dette tilfælde en vis mulighed for at. belyse værdien af Hoffmanns undersøgelsesmetode ved at sammenligne dette resultat med de sikre oplysninger om afstamning, som findes i materialet. En undersøgelse af indførslerne i selve borgerprotokollen for tiden

\footnotetext{
1)En summarisk oversigt herover for tiden efter 1735 er allerede givet af Frode Gribsvad i Festskrift til H. P. Hanssens s. 258 f.

2) Åbenrå præstearkiv: Stolestaderegistre 1567-1776.
} 
1740 - 1750, da oplysningerne om hjemsted er forholdsvis fuldstændige, giver følgende resultat:

\begin{tabular}{|c|c|c|}
\hline Byen . & $21,5 \mathrm{pc}$ & \\
\hline Nordslesvig iøvrigt & 32,8 & ” \\
\hline Angel $\quad \ldots \ldots \ldots \ldots \ldots \ldots$ & 1,1 & $»$ \\
\hline Flensborg og Slesvig $\ldots \ldots$ & 3,4 & $"$ \\
\hline Kongeriget $\ldots \ldots \ldots$ & 7,3 & $"$ \\
\hline Sverige $\quad \ldots$ & 1,7 & $x$ \\
\hline Holsten og Tyskland & 5,6 & $r$ \\
\hline Ubenævnte $\quad \ldots .$. & $26,6 "$ & \\
\hline
\end{tabular}

Det vil sige, hvis man regner Flensborg med til de tyske områder: 9 pct. fra tysk, 64,4 pct. fra dansk og svensktalende områder, 26,6 pct. uden oplysninger. Ser man bort fra de usikre, giver det 87,7 pct. nordiske, 12,3 pct. tyske. En bearbejdelse af Hoffmanns egen specificerede tabel over de borgere fra tiden $1721-50$, om hvem der foreligger oplysninger, giver 87,2 pct. og 12,8 pct. Her er altså den smukkeste overensstemmelse, hvad man derimod ikke kan sige, når man sammenligner med tallene i Hoffmanns almindelige tabel, der giver et meget større tysk indslag $i$ befolkningen. Fra et metodisk synspunkt vil det derfor under sådanne omstændigheder være rigtigst udelukkende at holde sig til de borgere, om hvem der findes oplys. ninger, og $\mathrm{i}$ hvert fald ikke blande de to beregningsmåder sammen.

Men hvad er nu grunden til de to vidt forskellige resultater? Der er uden tvivl flere. Det er allerede nævnt, at Hoffmann synes at anse navne for tyske, selvom de har været gæv og gængs i dansktalende områder allerede i middelalderen. Mere afgørende er det, at navnene jo ikke direkte oplyser, hvem der er indvandret, men kun hvor mange der bærer helt eller delvis tyske navne. Der findes ikke hos Hoffmann nogen klar redegørelse for, hvad han egentlig vil opnå gennem disse undersøgelser af navnene. Man skulle vente, at han, så vidt det nu er muligt, ville prøve at fastslå, hvem der er indvandret fra egne med fremmed nationalitet. Han synes dog nærmest at have tænkt sig på denne måde at kunne skelne mellem borgere af dansk og tysk "Volkstum«. Men et tysk navn i Åbenrå omkr. 1700 er ikke noget sikkert vidnesbyrd om tysk "Volkstum", da den pågældendes forfædre kan være indvandret mange generationer tilbage. Det rigtigste vil være at præcisere opgaven således, at man i den udstrækning, det er muligt, vil fastslå, hvem der er født i byen eller $i$ en egn af samme nationalitet som denne, $i$ dette tilfælde $i$ et område med dansk "Volkstum". Men det vil medføre, at kriteriet for afgørelsen af navnenes nationale hjemhørighed ændres, idet f. eks. tyske efternavne med danske fornavne i så fald må regnes som dan- 
ske. Denne mulighed synes ikke at være faldet Hoffmann ind, og han har derfor heller ikke foretaget tilstrækkelig indgående undersøgelser over navneskikkenes historie i de nordslesvigske byer. Der er ingen tvivl om, at det, i hvert fald efter 1600, har været almindeligt, at de faste slægtsnavne gik i arv, ja tit og ofte blev arvet på spindesiden. Og desuden var der også en tilbøjelighed til, at de fremmede særprægede fornavne blev bevaret fra slægtled til slægtled. Dette forhold gør undersøgelser på grundlag af navnestoffet yderst. usikre, og usikkerheden forøges, desto længere man kommer ned i tiden, og gør, at deres værdi i nyere tid, som tilfældet fra Åbenrå viste, må siges at være ret problematisk.

I sine statistiske oversigter arbejder Hoffmann med begrebet "gemischtes Volkstum«, hvilket er naturligt i et grænseland som Slesvig. Folk fra Flensborg og fra visse landsogne i Sydslesvig hører naturligt hertil. Men når han uden videre anbringer alle borgere fra de nordslesvigske byer $\mathrm{i}$ denne gruppe, er det med et mildt ord misvisende. Fordi folk har lært at tale og læse tysk gennem skoleundervisningen, der var tvungen, bliver de dog ikke af den grund "af blandet nationalitet«. Der kan ikke være tvivl om, at langt den overvejende del af byernes befolkning havde dansk som modersmål, først i skolen lærte de det tyske. Kun for børn af embedsmænd har dette delvis ikke haft gyldighed, men de har kun ringe interesse i denne forbindelse. Hvis man ikke vil gøre vold på den historiske sandhed, må folk fra de nordslesvigske byer henregnes til dansk "Volkstum", med mindre man i dette i sig selv yderst uklare udtryk vil lægge mere end sædvanligt, ikke nationalitet, men evnen til at tale og skrive et sprog. Anvender man denne fortolkning på nordslesvigerne efter 1864, vil det betyde, at langt den største del af Nordslesvigs dansksindede befolkning i 1920 var af blandet "Volkstum «.

Bogen om det slesvigske borgerskabs oprindelse er skrevet af en ung historiker. Man mærker det på mange måder, både $i$ en vis usikkerhed $\mathrm{i}$ den kritiske vurdering af kilderne og den metodiske udnyttelse af dem. Man mærker det også i den almindelige historiske viden, der for ofte ikke slår til eller helt svigter, hvilket også kommer frem i omtalen af de nationale forhold i Nordslesvig. Man savner et større udsyn, også til andre lande, og ikke mindst til Danmark og Tyskland, hvor et rigt materiale af tilsvarende art kunne have gjort sammenligninger mulig. Og man mangler ikke mindst en redegørelse for de mange problemer, der hænger sammen med borgerskabseden. Hvem skulle aflægge den, hvor mange aflagde den virkelig, d. v. s. hvor fuldstændigt er det materiale, der arbejdes med? Og man kunne have ønsket en dyberegående undersøgelse 
såvel af årsagerne til indvandringen som af borgerskabets rekrutering i det hele taget. Statistik løser nu engang ikke alle de historiske problemer, hvor værdifuld den end er. Men når disse indvendinger er fremført, må det også pointeres, at der her er tale om en ung historiker, der udsender sit første store værk. Der må indrømmes ham en vis margin. Og det skal til slut understreges, at Hoffmann er gået til sin store undersøgelse med en stædig energi og med en flid, der er ud over det sædvanlige. Han har aldrig givet op, når det gjaldt at finde det statistiske materiale, han skulle bruge, og ofte ligger talløse timers arbejde bag ved nogle få tabeller. Det materiale, han har fremlagt, er af så stor værdi, at det vil få den største betydning for alle fremtidige undersøgelser over lignende problemer og for beskæftigelsen med de enkelte byers befolkningsforhold. Samtidig må det understreges, at man har indtryk af, at Hoffmann har en redelig vilje til at gøre ret, når det gælder spørgsmålet dansk og tysk. Hoffmanns bog er - sine mangler tiltrods - en værdifuld forøgelse af den sønderjyske historiske litteratur.

JOHAN HVIDTFELDT

Troels Fink:

Sonderjylland siden genforeningen 11920

160 sider. Vi og vor fortid nr. 16 J. H. Schultz forlag 1955.

Med udsendelsen af denne bog, der fortsætter forfatterens »Rids af Sønderjyllands historie« fra 1945, er professor Finks skildring ført op til 1953-54. Af bogens 160 sider gælder de 120 tiden fra genforening til besættelse, mens tiden efter 1940 får ca. 40 sider, og Sydslesvigs historie beslaglægger knapt en trediedel af bogens samlede sidetal.

At fremstille det omhandlede tidsrums righoldige historie på så begrænset plads stiller store krav til forfatteren med hensyn til viden, overblik, fremstillingsevne -- og evne til at resignere over for stof. der kan forekomme uundværligt. Det skal straks siges, at professor Fink til fulde honorerer disse krav, således at resultatet er blevet en fremragende lille bog. Fremstillingen er stofmættet og dog let læst, den er klar og nøgtern, tiltalende ved sine rolige vurderinger af et medoplevet tidsafsnit, den giver gode muligheder for at se sammenhæng og vinde overblik over det brogede begivenhedsforløb siden genforeningen.

Til forskel fra ældre, ligeledes kortfattede bøger om mellemkrigstiden som Karl Rasmussens, Frede Nielsens og min, begrænser Troels 
Fink sig på forhånd til hovedsagelig at redegøre for den nationalpolitiske udvikling. Denne begrænsning må beklages, og forfatteren deler sikkert denne beklagelse. Hovedsummen af de forløbne 35 år under dansk styre er jo, som det så tit er sagt, genforeningsprocessens fuldbyrdelse. I denne proces samvirker et bredt kompleks af faktorer, hvori det nationalpolitiske indgår som en - naturligvis særdeles væsentlig - faktor blandt mange. Dette betyder selvfølgelig ikke, at økonomisk udvikling, jordkamp og skolepolitik lades uomtalt, men man savner eksempelvis en omtale af pressens rolle, den kirkelige udvikling og sider af det folkelige arbejde.

I skildringen af landsdelens danske historie er der ikke væsentligt nyt. Fremhæves skal den veldokumenterede redegørelse for $L$. S. bevægelsen i Sønderjylland og dens lederes kurs i de mørke kriseår. Værdifuld og velafvejet er tillige fremstillingen af forholdene i Sydslesvig. Her savnes dog en omtale af det særlige flensborgske socialdemokrati, hvis nu opløste partiorganisation på så ejendommelig måde var med til at præge udviklingen i Flensborg i det første årti efter Tysklands sammenbrud.

En kort, samlet oversigt over partier og valgtal både i Nord- og Sydslesvig vilde give bogen øget værdi på dette centrale felt.

For en dansk læserkreds er der derimod meget nyt $i$ afsnittene om det tyske mindretal. For første gang gives her $i$ en dansk fremstilling en sammenhængende og ret detailleret oversigt over faserne i mindretallets indre historie. Foruden de trykte kilder har professor Fink benyttet et betydeligt utrykt kildemateriale vedrørende tiden 1920-39. Dette kildestof bør snarest publiceres. En begyndelse er gjort med »Aktstykker til Kreditanstalt Vogelgesangs tilblivelse «. (Skrifter udg. af Historisk Samfund for Sønderjylland 1946). Jeg mener i denne forbindelse, at Historisk Samfunds styrelse bør betragte det som en af sine nærliggende opgaver at foranledige det øvrige hjemmetyske dokumentmateriale i dansk varetægt gennemgået med trykning for øje.

Ved læsningen af Troels Finks afsnit om mindretallet træder et karakteristisk træk igen frem i dets historie: fjernstyringen sydfra, som trådte så klart i dagen under besættelsen, har gjort sig gældende så godt som hele tiden efter 1920. På dansk side var det anderledes. Fra Ejderpolitikkens dage til skoleloven af 1946 lå de store afgørelser og dermed ansvaret hos landsdelens egne folk. Mindretallet var altid stærkt afhængigt af det store fædreland med hensyn til taktik og málsæetning.

For besættelsestidens vedkommende er grundlaget for skildringen det vældige materiale i Den parlamentariske Kommissions aktstykker bind XIV, som antagelig findes på alle biblioteker i vor landsdel. 
Forfatteren glemmer ikke de større perspektiver, hvor sammenhængen kræver det, linjerne til udviklingen såvel i Danmark og Tyskland som til begivenhederne på den storpolitiske arena er trukket instruktivt op.

Bogen er forsynet med to skolekort og en række billeder af førende mænd, blandt hvilke efter mit skøn også P. Marcussen havde fortjent en plads. Et register savnes.

Man må håbe, at Troels Fink skriver den til bunds gående, videnskabelige fremstilling af vor landsdels historie siden 1920, som kan afslutte den store Senderjyllands Historie med et 6 . bind. Tiden dertil må være inde.

\section{A. FEILBERG JORGENSEN}

\section{Ernst Siegfried Hansen:}

"Kurier der Heimat. Das Spiel um Schleswig zwischen Kapitulation und Programm Nord"

Deutscher Heimat-Verlag, Bielefeld. 480 sider.

Af undertitlen til redaktør Ernst Siegfried Hansens meget omtalte bog, "Kurier der Heimat" fremgår det, at han navnlig har onsket at beskæftige sig med begivenhederne på begge sider af den dansktyske grænse ud fra den betragtning, at der foregik et "politisk spil«. Han, den tidligere redaktør af det hjemmetyske organ "Der Nordschleswiger ", har fra første færd været med i dette spil, og der kan ikke herske tvivl om, at han har villet arbejde med på en udvikling, der skulle komme tyskheden på begge sider af grænsen tilgode. På den anden side har han også onsket at fremme disse bestræbelser ud fra en ærlig overbevisning om, at det ville være både nødvendigt og klogt at indtage en loyal holdning og fremkalde en national afspænding. Set på den storpolitiske baggrund har han ikke kunnet øje anden udvej.

Ernst Siegfried Hansen har haft gode forudsætninger for at kunne skrive en bog om grænsepolitikken siden 1945. For det første har han stáet midt $i$ begivenhederne og endog været kontaktmand, eller som han selv siger "Kurer" mellem ledende tyske personligheder både i nord og syd. For det andet må det siges, at han er en mand med udpræget politisk flair og med en solid politisk og journalistisk uddannelse. Det har han på særlig måde bevist i den tid, han efter at have forladt redaktørstillingen ved "Der Nordschleswiger" har virket som dette blads folketingsmedarbejder. Hans bedømmelse af den almindelige politiske situation her i landet viser, at han er en skarp iagttager, og det er den samme egenskab, der gør sig gældende i de betragtninger, han fremsætter i sin bog. 
Hans indstilling til Danmark og danske forhold er præget af velvilje. Det er ikke uden grund, han gør opmærksom på, at han nedstammer fra en bonde i Angel og fra en dansk bedstemoder fra Billum ved Varde, der ikke kunne have haft nogen anelse om, at whun skulle blive en gren på et tysk stamtræu. Med eller mod sin vilje er han uden tvivl "zweiströmig " uden at være tvesindet. Men netop derfor er det sikkert, at han har været i stand til nogenlunde uhildet at bedømme forholdene, således som de i de senere år har formet sig, om end subjektivt og set med tyske øjne. Han har loyalt stillet danske og tyske synspunkter over for hinanden, uden derfor at slå af på sine egne meninger, der fremtræder inden for en elegant publicistisk fremstillingsform, der både er dokumentarisk og kommenterende, men også billedskabende. Det gælder beretningerne om en række begivenheder og tildragelser, og det gælder de ikke så få personskildringer, der findes $i$ bogen.

Der kan af disse på dansk side nævnes mænd som Christmas Møller, Hans Hedtoft, Frede Nielsen og Knud Kristensen, og det er de bedste. Men ogsá portrætter af tyske personligheder er læseværdıge, selv om de vel for nogles vedkommende ikke er kritiske nok og måske savner en stærkere psykologisk baggrund. Men man får dog gode skildringer af mænd som Fr. Wilh. Lübke, Andreas Gayk og Kai- $U$ we von Hassel. Ikke mindst den fhv. finansminister Dr. Richard Schencks politiske personlighed og skæbne har krav på opmærksomhed, fordi den så at sige har været analog med den politiske og folkelige udvikling i graenselandet $i$ løbet af det svundne årti.

Inden for det samme åremål er det, at Ernst Siegfried Hansens bog giver et indtryk af den nationale, folkelige og politiske spænding både i Sydslesvig og i Nordslesvig. Han har tegnet et bredt, men livligt varierende billede af begivenhederne og dermed af den grænsepolitiske og folkelige problematik, der har behersket både drøftelserne og de tagne beslutninger lige siden den danske regerings af frihedsrådet godkendte erklæring om at grænsen ligger fast. Man får et indtryk af det tyske mindretals holdning efter kapitulationen, af tyske og danske politikeres stilling til den danske bevægelse i Sydslesvig, af stillingen før og efter valgene i Slesvig-Holsten og i Nordslesvig, og endelig af forfatterens egen delagtighed i det politiske spil, der knyttede tråde mellem tyskere på begge sider af grænsen og fik betydning for den følgende udvikling. Til slut får man en redegørelse for "Programm Nord", som den genopbygning, der siden 1920 har fundet sted i Nordslesvig, ifølge Ernst Siegfried Hansen skal have givet afdøde ministerpræsident Lübke ideen til.

Det er en bog, der kan give både danske og tyske læsere et ud- 
mærket indtryk af den udvikling, der $\mathrm{i}$ de senere år har fundet sted på begge sider af grænsen. Man har her et samlet indtryk af begivenhederne, som kan danne baggrunden for skildringen $i$ en følgende bog, i hvilken Ernst Siegfried Hansen særlig vil beskæftige sig med forholdene i Danmark og Nordslesvig og naturligvis også med det, der er sket siden den her omtalte bog så dagens lys.

MORTEN KAMPHOVENER

Frode Beyer:

Valdemar Ammundsen. Liv og tanker. 1954

Da kirkehistorikeren A. i 1923 fra Københavns universitet flyttede til det ved genforeningen nydannede Haderslev stifts bispestol, var det en med grænselandets forhold i forvejen fortrolig mand, som tog en betydningsfuld gerning op $i$ det genvundne land. Fra barnsben af havde han fulgt med i "Flensborg Avis». Hans rektor i Kø: benhavn, den kendte Johs. Helms, forud i Slesvig, har formentlig også i ham - som i andre elever, f. eks. seminarieforstander E. Albeck - vakt en dyb kærlighed til det tabte land og den folkelige kamp hernede. A.'s opsigtsvækkende og skelsættende ordskifte med Johs. Tiedje i »Die christliche Welt« 1909 om den prøjsiske tvangskurs i grænselandet og med M. Rade og Johs. Tonnesen i 1919 om den danske fremtid havde gjort hans navn kendt og agtet sønden å. Historiske arbejder som "Den unge Luther" (1907), "Krig og krigsførende Kristne" (1915), "Den kristne Kirke i det 19. Aarhundrede (1925) havde vist hans store viden om samtidens åndsliv og dets historiske forudsætninger. Selv betragtede han det som en højere førelse, at han fik sin afsluttende livsgerning i det genforenede land.

Provst Beyer i Rinkenæs, som kalder A. sin læremester, lader os nu i sin velskrevne bog følge A.'s udvikling og livsindsats. Det.sker på den måde, at det overvejende er $A$. selv, som ved fremdragne trykte og især utrykte ting (dagbøger og breve) fører ordet. Det er lykkedes smukt og giver en historisk værdifuld indsigt i A.'s liv og tanker. I særlig grad har forf. søgt gennem uddrag af dagbøgerne at klarlægge A.'s personlige meditationer, hans lønkammertanker, af hvilke hans handlinger siden sprang frem. Vi får et stærkt indtryk af hans både midtpunktsøgende og vidt favnende ånd. Den historiske vurdering af A.'s gerning overlades til senere biografer. - På dette sted vil nogle bemærkninger til biskop A.'s indsats i grænselandet vel være af interesse. 
Som biskop betragtede A. sig som den første præst i stiftet mere end som administrator. Det var som den kirkelige forkynder og foredragsholder, han færdedes i stiftets menigheder og samlede præsterne til stiftskonventer. Han optrådte her altid som talsmanden for bevarelsen af den historiske kontinuitet i de kirkelige forhold. De sønderjydske menigheder skulle således ikke straks skifte salmebog, tilmed når den slesvigske salmebog stort set var værdifuldere end den kongerigske. A. har afgørende andel $i_{\text {, at vi } i} 1925$ foreløbig fik en sønderjydsk salmebog, idet en del dødt stof af den slesvigske udgik og i stedet det savnede danske, især salmer af Grundtvig, optoges $i$ et tillæg. Også ellers i gudstjenesteskikkene søgte $A$. at bevare en kontinuerlig linje uden de skarpe brud, så de sønderjydske menigheder kunne vokse sig ind $i$ dansk menighedsliv og selv medbringe værdifulde impulser. Tre nye kirker fik A. den glæde at indvie, i Vojens, Rinkenæs og Genner. For præsterne har hans omfattende viden og ireniske sind utvivlsomt været til stor hjælp i disse nybyggerår, fyldte af politisk gæring og deraf følgende sjælelige konflikter. Han var en forstående vejleder for tyngede sind.

Kirkepolitisk gik $\mathrm{A}$. som bekendt både af historiske og kirkelige grunde ind for bevarelsen af "helsognspræsten « fra tysk tid, der da i de nationalt blandede sogne måtte være "tvésproget«. Han begrundede sit syn med, at ligesom menighedens herre er een, må også hans menighed lokalt være een, hævet over menneskelige skillelinjer, også de nationale. Denne "A.ske linje« lå i nogen grad på tværs af det sønderjydske kirkeudvalgs synspunkter, fødte ud af erfaringerne fra tysk tid. Den har da også i tidens løb vist sig ikke at være den bedst egnede ramme for en nationalt blandet befolkning. Mindretallet $i$ et sogn kan i hvert fald folkeligt $i$ regelen ikke være tjent med flertallets præst. Hvert folk må helst have sin præst ud af sin egen midte. Tyskerne protesterede da også straks fra begyndelsen imod den A.ske linje og oprettede tyske frimenigheder og danskerne i grænsesognene med tyske sognepræster gjorde siden det samme. Tyskerne var tilfredse, så længe sognets præst var een af deres egne .Men en tvesproget dansk præst, som A. nogle steder fik beskikket, afvistes næsten overalt. A.'s linje har utvivlsomt tjent kontinuiteten i udviklingen og har som sådan haft sin overgangsberettigelse. Men ellers har den ikke vist sig egnet og har da også bragt A. selv adskillig skuffelse.

Kristendommens grundlæggende kærlighedsbud og oplevelsen af den første verdenskrigs dæmonier havde gjort A. til fredens og forsoningens ven, der utrætteligt gik ind for forståelse og udligning mellem folkene ude og hjemme. Frugterne af denne hans fredsstiftende gerning her i grænselandet er det vanskeligt at dømme kon- 
kret om, men de er uden tvivl betydelige og har på den indre front bidraget afgørende til genforeningsprocessens lykkelige udfald. Også fra tysk side blev den nye danske grænselandsbiskop afgjort mødt med tillid. Når han talte om "vor fælles reformator Luther", som han var første rangs kender af, lyttedes der fra begge sider og skabtes der forbindende kirkelige bånd. Men her brød i 30'rne nazismens nationale hedenskab ind og forstyrrede freden. Han skånedes ved sin tidlige død for at opleve dens videre hærgen. Hans eget-standpunkt er udtrykt $i$ en sætning som denne: "Hvor Kristendommen faar Lov at raade, virker den paa een Gang nationalt styrkende og internationalt forenende."

A. nåede som aktiv deltager i den internationale kristne studenterbevægelse og som Søderbloms økumeniske medarbejder og afløser i Norden tilsidst frem til en ledende international kirkelig stilling og har uden tvivl bidraget væesentligt til at vække goodwill i verdenspolitikken for den løsning af mindretalsspørgsmålet, som Danmark - som man sagde - pả forbilledlig vis gennemførte i sit grænseland og han selv havde afgørende del $i$. Også et personligt bidrag til, at denne Versailles-grænse viste sig at være den eneste, som holdt under nazismens voldspolitik.

Biskop A. havde, udrustet med rige åndsevner, i sit liv og virke bedt sig frem til »den visdom, ... som ydmyghed er sjælen i«. Han var ud fra sin kristne livsindstilling i udpræget grad formidleren, både teologisk-kirkeligt og nationalt-socialt, og indtager som sådan en betydelig plads i den historiske genforeningsproces efter 1920. I "Sønderjyllands Historie« (1930 ff.) skrev han sin værdifulde oversigt over "Det aandelige Liv" 1864-1920. Hans eget åndsbårne liv skrev selv historie efter 1920.

JENS HOLDT

\section{P. Ingwersen:}

Methodisches Handbuch für Heimatforschung.

Aufgezeigt am Beispiel Schleswig-Holstein. Gottorfer-Schriften zur Landeskunde Schleswig-Holstein III, 1954, $328 \mathrm{~s}$.

Interessen for hjemstavnsforskningen har i Slesvig og Holsten i de sidste årtier været stor og er stadig stigende. Foregangsmændene i dette arbejde er folkeskolens lærere, som gennem deres uddannelse på de pædagogiske højskoler er bedre forberedt til at deltage i udforskningen af hjemstavnens historie og natur end danske lærere gennemgående er det. De virker som tillidsmænd for hjemstavnsforeningerne og fylder de mange hjemstavnsskrifter med gode og lødi- 
ge artikler. I adskillige landsbyer og sogne er med lærerne som ledere dannet større eller mindre arbejds- og studiegrupper, som systematisk er gået $i$ lag med indsamling af materiale til beskrivelse af deres sogn eller by $i$ fortid og nutid med det mål for øje engang at få en sognebeskrivelse udgivet. Adskillige af sådanne hjemstavnsbøger foreligger på tryk og er vidnesbyrd om, at man er gået i gang med de mange og vidtspandende undersøgelser med stor ihærdighed og dygtighed.

Der er en væsensforskel mellem hjemstavnsforskningen syd for grænsen og det lokalhistoriske arbejde nord for, idet tyskerne i deres hjemstavnsbøger og tidsskrifter medtager skildringer af geologiske, zoologiske, botaniske og meteorologiske forhold. Dette medfører sikkert, at flere ud fra forskellige synspunkter og interesser slutter op omkring hjemstavnsarbejdet, men kan vel også føre til en uheldig spredning af interesserne hos den enkelte deltager $\mathbf{i}$ dette. Den nye af dr. P. Ingwersen redigerede vejledning $i$ hjemstavnsforskning følger de gamle veje og indeholder derfor afsnit om naturfagene som led i hjemstavnsforskningen. I det indledende kapitel giver dr. Ingwersen, der er kendt som en særdeles habil lokalhistoriker og tillige er den inciterende leder af "Arbeitsgemeinschaft für Landes- und Volkstumsforschung in Schleswig", en overcentral for hjemstavnsforskningen, en række råd vedrørende dennes praktiske tilrettelægning. Han anbefaler dannelsen af arbejdsgrupper i sogne og byer ud fra den opfattelse, at arbejdet ved en opdeling af opgaverne mellem flere, efter interesser og anlæg, lettere kan fore til et resultat, end hvis en enkelt mand skulde bevæge sig over det vide felt, som den tyske hjemstavnsforskning spænder over. Målet for en arbejdsgruppe må være en trykt kronik, en sognebog vilde vi vel nærmest kalde den, men dr. Ingwersen understreger, at det vil være forkert at fremskynde trykningen på bekostning af nøjagtigheden og fuldstændigheden og henviser i denne forbindelse til at foreløbige resultater kan publiceres ved duplikering eller i kredsårbøger og dagblade. Vejledningen på de enkelte fagområder gives af fremtrædende slesvig-holstenske videnskabsmænd og pæedagoger. Landesbibliotheksdirektor, dr. Olaf Klose lægger for med en oversigt over biblioteksvæsenet og vejleder $\mathbf{i}$ biblioteksbenyttelse. En ret omfattende systematisk litteraturfortegnelse over bibliografiske hjælpemidler, trykte kilder, tidsskrifter, sognehistorier m. v. vil også med udbytte kunne udnyttes af nordslesvigske lokalhistorikere. Indiørelsen i arkivstudiet gives af lederen af det slesvig-holstensko Landesarchiv på Gottorp, dr. G. E. Hoffmann og Landesarchivrat, dr. K. Hector. Dr. Hoffmann giver en almindelig oversigt over det slesvig-holstenske arkivvæsen og en elementær vejledning $i$ arkivbe- 
nyttelse. Også her fastslås reglen, at lokalhistorikere bør begynde deres undersøgelser $\mathrm{i}$ de små embeders, de underordnede instansers arkiver og fra dem over melleminstanserne arbejde sig frem til centraladministrationens store arkivmasser. I modsætning til her i landet er præsteembedernes, kommunernes og underøvighedernes arkiver som regel ikke afleveret til Landesarchiv, men opbevares lokalt, hvorved de uden rejser og omkostninger kan udnyttes af lokalhistorikerne. En særlig omtale giver dr. Hoffmann folketællingslisterne og de arkivalske kilder til skolehistorien, men man undrer sig her lidt over, at han ikke næuner de vigtige indberetninger og inventarier fra 1709-10 og 1763 ff. Dr. Hector giver en klar og særdeles instruktiv oversigt over forvaltningen og retsplejen før $1864 \mathrm{og}$ tager enkelte af lokalhistorikere hyppigst benyttede arkivalier frem til særskilt behandling, nemlig amtstueregnskaberne, skyld- og panteprotokollerne, der også omtales af dr. Hoffmann, udskiftningsakterne og de få lægdsruller, der er bevaret fra Sydslesvig. For Nordslesvigs vedkommende er antallet af sidstnævnte arkivalier større, og det kan i denne forbindelse næunes, at der i landsarkivet i A benrå opbevares lægdsruller fra begyndelsen af det 19. årh. fra 2. angler godsdistrikt, der også omfatter godser, som nu ligger syd for grænsen. På kirkebøgerne, der i Sydslesvig som regel opbevares ved præsteembederne, ofres der en ganske særlig omtale, idet Detlef Thomsen har fået tildelt ikke mindre end 25 sider til at redegøre for, hvorledes deres indhold ved udarbejdelse af alfabetiske registre kan gøres lettere tilgængeligt for slægts- og lokalhistorikere og hvorledes der på grundlag heraf kan udarbejdes sogneslægtsbøger. En her anbragt fortegnelse over allerede registrerede kirkebøger vilde have været meget nyttig. Dr. Hans Hingst skriver om amatørarkæologernes arbejde og dets begrænsning. Der redegøres bl. a. for fredningsbestemmelserne $i$ henhold til den tyske fredningslov, og man kan på baggrund heraf ikke rigtig forstå, at det ikke har været muligt for de tilsynsførende myndigheder at optræede mere virkningsfuldt overfor ødelæggelserne på Dannevirkeanlægget. Kapitlerne om geologi, meteorologi, botanik, zoologi og naturfredning skal ikke nærmere omtales her, medens der er al god grund til at dvæle lidt ved professor Carl Schotts afsnit »Siedlungs- und Wirtschaftskunde", hvori der under en erhvervsgeografisk synsvinkel vejledes $i$ mange af de spørgsmål, som hjemstavnsforskerne må beskæftige sig med. Under henvisning til forbilleder og kilder peges på de mange forhold af materiel karakter, der må tages op til nærmere undersøgelse, emner der også må henregnes til centrale afsnit i danske sognehistorier, som på bredt grundlag tilstræber at give en skildring af fortidens mennesker og de vilkår, hvorunder de levede og virkede. Professor 
Schott nævner undersøgelser vedrørende det dyrkede areals udstrækning gennem tiderne, vedrørende dyrkningsmåde, skove og heder, udskiftning, kvæghold, vejnet, besiddelsesforhold, befolkningens sociale opbygning, bebyggelsesformer og bygninger, altsammen set i historisk perspektiv. Undersøgelser af denne art kræver indgående studier, men er dog ikke mere omfattende og krævende, end at habile lokalhistorikere vil kunne gå i lag hermed. Studienrat, dr. Chr. Degn kommer i kapitlet om sociologien ind på nogle af de samme emner under en noget æendret synsvinkel, og det samme er iøvrigt tilfældet med rektor Chr. Petersen i hans kapitel om nutidskroniken. Der er i de tre kapitler, navnlig i de to sidste, mange gentagelser, som med en anden disposition af bogen kunde være undgået. Af særlige emner, som fremdrages af dr. Degn og rektor Petersen, kan nævnes de aktuelle spørgsmål om forholdet mellem tyske og danske, mellem flygtninge og hjemmehørende og mellem de forskellige klasser og sociale lag. Skolehistorikeren, dr. Ernst Erichsen behandler emnet, hvorledes en skoles historie kan skrives og giver som vejledning en meget detailleret disposition herfor, medens fhv. rektor J. Grønhoff giver en oversigt over de litterære kilder til skolehistorien. Til sidste må bemærkes, at udvalget af litteraturen er ret tilfældigt og i hvert fald for Nordslesvigs vedkommende ensidigt.

Mange lokalhistorikere har med krum hals kastet sig ud i tydningen af stednavne og er ofte nået til højst besynderlige resultater, ikke mindst gælder dette i Sydslesvig. Dr. Wolfgang Laur, der skriver om stednavneforskningen og dens betydning for studiet af forhistorien og bebyggelseshistorien, understreger da også med rette, at tydningen af stednavnestoffet kræver sådanne filologiske forudsætninger, at ikke-fagfolk bør afholde sig herfra. Derimod kan hjemstavnsforskerne være behjælpelige ved indsamling og optegning af stednavne. Dr. Laur vedføjer et par skemaer, der kan bruges som mønstre ved optegningen. I forbindelse hermed kan nævnes, at der også gives korte vejledninger i studiet af folkemålene. Professor G. Cordes behandler plattysk, medens professor Hans Kuhn tager sig af dansk og frisisk. Et så nyttigt hjælpemiddel som Fejlberqs Ordbog over jydske Folkemaal nævnes lige så lidt som Skautrups nve sproghistorie eller Allen: Det danske Sprogs Historie i Slesvig. Når lokalhistorikere i Sydslesvig skal skaffe sig oplysninger om sproget i deres sogn $\mathrm{i}$ ældre tid er disse håndbøger dog ganske uundværlige. Folkloristen Paul Selk skriver klogt og inspirerende om nedtegning af den folkelige overlevering, og museumsmanden, dr. Ernst Schlee redegor for undersøgelser og indsamling af materiale vedrørende den gamle folkekultur, bygninger, inventargenstande, redskaber, arbejdsprocesser, folkekunst $\mathrm{m}$. v. 
Til de fleste af kapitlerne er der føjet mere eller mindre omfattende litteraturoversigter, men der er i disse oversigter og dr. Kloses bibliografiske tillæg så mange gentagelser, at det efter anmelderens opfattelse yilde have været rigtigst, om det var blevet overdraget dr. Klose at samredigere de forskellige litteraturoversigter. Man kunde have indvundet ikke så lidt plads, og det vilde herved være blevet muliggjort at skaffe plads til at nævne en række danske værker, som man forgæves leder efter $i$ fortegnelserne, men sore sagt $i$ al beskedenhed vilde kunne være de slesvig-holstenske lokalhistorikere til nytte.

Bogen giver på flere områder værdifulde anvisninger og råd, som vi også her i Nordslesvig vil kunne tage ved lære af. Men det kunde vel $\mathbf{i}$ og for sig også tænkes, at der syd for grænsen fandtes en eller flere lokalhistorikere, som kunde onske at skrive en almindelig sognehistorie efter dansk mønster uden de naturvidenskabelige afsnit og spændende over oldtid og middelalder til nutid. Spørgsmålet bliver da. om man kan finde den fornødne vejledning hertil i den nye håndbog. Man finder $i$ dr. Kloses bibliografi for middelalderens vedkommende kun fả af titlerne på de trykte kilder, som bør undersøges, og en særskilt behandling af problemerne omkring arbejdet med det middelalderlige stof $i$ en sognehistorie findes ikke. Noget så centralt $i$ en sognehistorie, som kirkehistorien må være, gi ves der heller ingen vejledning i. Disse kritiske bemærkninger bunder vel ti] syvende og sidst $i$ den forskel, der nu engang er mellem en stysk hjemstavnsforskers « og en "dansk lokalhistorikers « målsætning. Men i alle tilfælde må det siges at være en mangel, at der ingen vejledning gives i manuskripters tilrettelægning for trykning, klicheers anbringelse, korrekturlæsning $\mathrm{m}$. $\mathrm{v}$., elementære ting. som ofte kan volde den uerfarne forfatter eller redaktør unødige vanskeligheder.

PETER KR. IVERSEN

\section{Horst Windmann:}

Schleswig als Territorium. Grundzüge der Verfassungsentwicklung im Herzogtum Schleswig von den Anfängen bis zum Aussterben des Abelschen Hauses 1375.

"Quellen und Forschungen zur Geschichte Schleswig-Holsteins « Band 30. Neumünster 1954.

Hovedtitlen på denne kielske doktordissertation kunne nok ved første blik se ud til at dække over en topografisk undersøgelse. Den omstændelige undertitel lader imidlertid forstå, at "Territorium " skal 
tages i den betydning, ordet har i tysk rets- og forfatningshistorisk sprogbrug: et område, hvor en landsherre gennem udøvelse af domsmyndighed og forvaltning samt ret til skatter hævder sin indflydelse over omrádets beboere, uafhængigt af rigsmyndighederne. Trods uenighed om enkelthederne ved udviklingen af disse territorier er der - som Windmann siger - nogenlunde enighed i forskningen om, at de dannedes fra neden, idet de små magtområder udkrystalliseredes omkring fyrsternes udøvelse af de nævnte juridiske og forvaltningsmæssige rettigheder.

Horst Windmann har nu gennemgået den tidligste slesvigske forfatningsudvikling for at fastslå de vigtigste etaper i udviklingen af et slesvigsk hertugdømme og for at sammenligne med den tilsvarende tyske udvikling. Hovedresultatet af hans undersøgelse bliver da, at den hertugelige magt "fra oven og udefra indføjedes $i$ den bestående danske rigsordning «. Hertugen overtog simpelthen i området mellem Ejderen og Kongeåen efterhånden de rettigheder, kongemagten $\mathrm{i}$ tidens løb havde sikret sig. Dog forbeholdt kongemagten sig en del af rettighederne, uden at en nøjagtig afgrænsning af hertugens og kongens beføjelser på hvert enkelt tidspunkt lader sig foretage.

Denne udviklingslinie og især den kendsgerning, at de sønderjyske hertuger - så lidt som de danske konger - fik ændret landstingenes stilling i retsordningen som indehavere af den dømmende magt, står i betydelig modsætning til den lige skitserede tyske udvikling. Holder man sig til de snævre definitioner, er det måske derfor med tvivlsom ret, ordet territorium bringes i forbindelse med Slesvig. Windmann understreger også, at bindingen til danske institutioner og sædvaner i den betragtede periode afgjort er stærkere end indflydelsen fra syd. Tilmed kom europæisk og specielt tysk påvirkning i hærvæsenet, hofholdningen, lenssystemet etc. til Slesvig via Danmark. Kun den overordentlige skat, beden, mener Windmann er af holstensk oprindelse. Og selv da den holstenske indblanding for alvor tog fat i 14. årh., bevaredes områdets danske struktur juridisk, skattemæssigt, forvaltningsmæssigt o.s.v. Blot var nu hertugen indskudt i systemet dels på kongens plads dels som et mellemled mellem kongemagten og landsdelens beboere.

Det følger heraf, at en stor del af bogen må optages af en redegø. relse for den danske kongemagts udvikling i 11.-14. årh. Forf. byg. ger her overvejende på de sidste menneskealdres danske forskning. og fremstillingen kan derfor ikke på alle punkter virke ny for dan ske læsere. Med megen lærdom og stor viden har Windmann i enkeltheder undersøgt, hvad der på det spinkle, tit selvmodsigende kildestof kan bygges af viden om grundlaget for kongemagtens (og 
dermed oftest hertugens) rettigheder og muligheder for magtudfoldelse.

En nyere tids fornemmelse af, at en stærkere nuancering $i$ betragtningen af udviklingstendenserne i middelalderen er nødvendig. så kildernes oplysninger ikke tidsmæssigt udnyttes alt for vilkårligt, er tydelig hos Windmann. Derved bliver han i stand til at give Knud Lavards sønderjyske jarledømme en delvis ny belysning. I et tillæg gives en kritisk behandling af kilderne til Knuds historie, og på grundlag af de meget sparsomme oplysninger, der har kildeværdi, kommer Windmann til det resultat, at Knuds magt fortrinsvis var baseret på herredømmet over Wagrien og i det sydligste Slesvig samt på besiddelsen af selve byen Slesvig. Derimod har hans magtområde næppe omfattet de 3 sønderjyske sysler, Barvid, Ellum og Isted, således at der hverken territorielt eller retsligt er forbindelse mellem Knuds jarledømme og det senere hertugdømme Slesvig.

Denne manglende sammenhæng i udviklingen er væsentlig i Windmanns fremstilling, da hans hovedsynspunkt jo som nævnt er, at først Valdemarstidens kongemagt med dens nogenlunde afgrænsede beføjelser og rettigheder betingede hertugdømmets udskillelse. Rettighederne kunne nu i større eller mindre omfang overføres til hertugen. Kongemagtens forsøg på at hævde kronens arvelighed spillede her en rolle, idet tendensen til at anbringe den næstældste kongesøn som sønderjysk hertug var en følge af denne politik.

Stort set har forf. undgået en for snæver juridisk betragtning af de forfatningsmæssige fænomener, der er sat ind i en historisk sammenhæng. Derved træder deres afhængighed af de politiske faktorer tydeligt frem, hvad man kan se i forbindelse med de holstenske grevers indblanding, der dels støtter Abelslægtens bestræbelser på at opnå en frigørelse fra kongemagtens indflydelse, dels fører til en indskrænkning af hertugdømmets omfang og økonomisk svækkelse af hertughuset. - Nogle steder havde man dog været glad for en forklaring af, hvordan de faktiske tilstande stillede sig $i$ forhold til de ofte uklare retslige bestemmelser, når en undersøgelse heraf da vel at mærke lader sig gennemføre. Eksempelvis anfører forf. (s. 151, note 283) til karakteristik af landstingenes selvstændighed overfor kongemagten bestemmelsen i håndfæstningen af 1282 om, at de kongelige ombudsmænd ikke kan stævne nogen for sig, men er bundet til landstinget. For en historisk betragtningsmåde vil det nok være rimeligt at regne med den mulighed, at forbudet netop er medtaget, fordi en sådan praksis fandt sted, men vakte uvilje.

Horst Windmanns kendskab til den danske middelalderforskning er imponerende og hans benyttelse af dens resultater og synspunkter præget af indsigt og loyalitet. Hans meget omfattende litteratur- 
liste, der også medtager bøger, han ikke har kunnet benytte, viser, at han stort set har orienteret sig om alt, hvad der kan have betydning for emnet. Enkelte ting som Flensborg bys historie og den nye udgivelse af Danmarks gamle købstadlovgivning er dog undgået hans opmærksomhed, så han kommer for skade at erklære, at Haderslev stadsret sidst er trykt af A. Sach i 1892. Desuden kan det måske siges, at han i lidt for høj grad bygger på Poul Johs. Jørgensens retshistorie uden tilstrækkeligt at forbinde dennes retshistoriske anskuelse med den historiske forsknings metoder og resultater.

Bogen er naturligvis i høj grad præget af den tyske sans for udarbejdelsen af omhyggelige og udførlige noter. Disses antal løber helt op til 1257 på de 203 sider. Temmelig overflødigt forekommer det, at så godt som alle optryk af de enkelte kildesteder opføres. Det gælder især henvisningerne til Hasses regestværk, hvor forf. i en række tilfælde må gøre opmærksom på fejl og misforståelser i regesterne, så de fleste af henvisningernes værdi er tvivlsomme. Det er spild af energi og omhu, som passende kunne have været anvendt på korrekturlæsningen.

Denne synes nemlig at have svigtet totalt. Bogen vrimler med trykfejl, ombryderfejl og forkerte krydshenvisninger (også til kapitler, der slet ikke eksisterer) $\mathrm{i}$ et omfang, man heldigvis ellers sjældent kommer ud for. Forhåbentlig hænger det sammen hermed, at H. V. Clausen konsekvent forsynes med forbogstaverne H. C., der endog forfølger ham helt om i biografien, at øen Hjelm anbringes som en lokalitet i Nordjylland, at der opereres med en mærkelig langelandsk by "Downs", der iøvrigt slet ikke omtales i det citerede dokument, at Erik V forsynes med Kristoffers dødsår (1259) o. m. a. Det er jo ellers fejl, der nok kunne skabe en sagte tvivl om dybden af Windmanns kendskab til danske forhold, og denne tvivl kunne næres af det unøjagtige referat af begivenhederne $i$ forbindelse med Hindsgavlforliget 1295. Men antagelig er det bare sjusk, og man skal måske i denne forbindelse ligefrem glæde sig over, at bogen ikke er forsynet med register, hvis udarbejdelse jo kræver stor omhu. Manglende register er ellers en uting ved en bog af denne art. Ganske vist er den let at læse, men man ville være glad for at have et hjælpemiddel til også senere at udnytte dens mange udmærkede oplysninger uden at skulle lede alt for længe efter dem.

De anførte mangler må nemlig ikke tilsløre den kendsgerning, at vi her har fået et værdifuldt bidrag til sønderjysk historie i middelalderen, som nok skal blive brugt i fremtiden. Århundrederne efter 1241 er jo kun svagt behandlet fra dansk side. Alle problemer har Windmann ikke løst, og fagfolk vil nok finde anledning til en og 
anden korrektur, bl. a. som følge af hans lovlig frimodige trang til på en række punkter at tage kildernes tavshed til indtægt for vidtgående slutninger. En farlig og betænkelig metode. Men bogen er god, og det er med fuld føje, dr. Olaf Klose har sørget for dens fremkomst i det slesvig-holstenske historiske selskabs serie "Quellen und Forschungen «.

HANS P. CLAUSEN

\section{H. V. Gregersen:}

Messe og marked. Det landskendte Kliplev marked. (Folkeligt forlag. Struer) 1955.

Adjunkt H. V. Gregersen er ikke ukendt for Sønderjydske årbøgers læsere. Arbøgerne har bl. a. bragt afhandlinger af ham om Åbenrås økonomiske historie indtil ca. 1730 , om den nationale vækkelse i landsognene omkring Åbenrå, om Slogsherreds nationale historie og om Johs. Kok og skolevæsenet i Burkal sogn, afhandlinger, der er bygget på historiske kildeundersøgelser. Han har også været en flittig medarbejder ved Sønderjydsk månedsskrift og Sprogforeningens almanak. Det er emner af lokalhistorisk art fra Åbenråegnen og fra den nationale vakkelsestid for hundrede år siden, han har behandlet.

Det er da også et sådant bidrag til sønderjydsk lokalhistorie, han har leveret $\mathrm{i}$ den nylig udkomne bog om Kliplev marked, hvor han har fremdraget meget ukendt stof af hidtil ubenyttede kilder.

Bogen indledes med et kapitel, "Under skiftende herrer", hvori der gives en kort oversigt over Søgårds historie fra Limbekerne og Ahlefeldterne over godsinspektørernes tid under Ahlefeldternes efterfølgere til amtmand Heltzen. Derefter vender forfatteren sig til selve Kliplev som valfartssted til helgenen skt. Hjælper, der er selve Kristus. Der fandtes også andre helgensteder for skt. Hjælper i landet, men Kliplev var langt det berømteste. Når dronning Margrethe anordnede pilgrimsrejser efter hendes død bl. a. »til thet hælghekors sancte hjælp ", er der sikkert hermed ment Kliplev. Forøvrigt er det ikke meget, man ved om valfarten hertil. Helgenbilledet blev fjernet efter reformationen, omend måske ikke lige straks, i hvert fald dog inden 1710, men skal endnu 1808 have ligget på kirkens loft.

Til valfartssteder blev der ofte knyttet markeder, således også her, hvor tilmed korsmessetiderne faldt sammen med de tider, hvor de store studedrifter ad hærvejen ned gennem landet fandt sted ved forårs- og efterårstider. Så blev Kliplev marked da det store studemarked. Herom fortælles der i de følgende kapitler: Fra valfart til marked, Termin og forkøb, "Jyllænderne« og Kliplev, »Det fornemste 
og considerableste marked i 50 miles afstand “. Nu flyder kilderne rigeligere, og forfatteren fortæller levende om, hvorledes $\mathrm{i}$ den til daglig så stille og rolige landsby ved markedstiderne markedspladsen og landsbygaden fyldtes af stude $i$ hundredevis og af prangerne, og hvorledes der i de dage levedes et hektisk liv med handel og lidkøb, hvor snart hvert hus i byen havde tilladelse til at holde udskænkning af brændevin, som man hentede i Flensborg, og af øl, som man i hvert fald senere hentede i Åbenrå, og til beværtning med mad forfatteren giver os spisesedlen for de forskellige måltider de 2 dage - og til at logere de tilrejsende om natten. Forfatteren har gennempløjet justitsakterne i Søgård godsarkiv og giver i kapitlet "Skæbner og tildragelser « en del emksempler på, hvad de fortæller om mærkelige skikkelser, om tyveri og drik, om handel uden tilladelse og meget mere. "De kuriøseste tildragelser har kunnet finde sted; og ingen behøvede derfor at kede sig, når der var marked i Kliplev. Det var dage, som en hel egns befolkning sammen med folk langt borte fra så hen til i spændt forventning. Der har alle dage været noget tillokkende ved Kliplev marked «, siger forfatteren.

Der blev aldrig rigtigt givet tilladelse til krammarked $\mathbf{i}$ forbindelse med kvægmarkedet, men de handlende mødte alligevel med deres kram. Undertiden søgte ovrigheden at komme det til livs, men det lykkedes aldrig. Stærkest forsøgte man at forbyde det $\mathbf{i}$ tysk tid. Befolkningen klagede da over, at man mátte lade konerne og børnene og tjenestefolkene blive hjemme, for der var ikke længere noget for dem at komme til Kliplev marked efter, ja, man kunne ikke engang få en "present" med sig til dem derhjemme. Det lykkedes da heller ikke dengang at få krammarkedet slået ned. Men tiderne forandredes. Banen kom, og kvægdrifterne ad hærvejen hørte op. Nok førtes studene nu til markedet ad banen, men Kliplev marked var ikke længere, hvad det før havde været. Forfatteren har her sat det et minde ved at fortælle dets historie, livligt og levende, også set på en større baggrund, f. eks. i kapitlerne "Mod nye tider « og »Folkelige brydningsår«. 


\section{Bognyt}

Geschichte- Schleswig-Holsteins. Begründet von Volquart Pauls. Im Auftrage der Gesellschaft für Schleswig-Holsteinische Geschichte herausgegeben von Olaf Klose.

Som det vil ses af denne árbogs anmeldelser og litteraturfortegnelser arbejder den videnskabelige slesvig-holstenske historieforskning $i$ disse år overordentlig energisk og målbevidst. Ledelsen af dette arbejde er lagt $\mathbf{i}$ hænderne på Gesellschaft für Schleswig-Holsteinische Geschichte, der foruden de tre tidsskrifter Zeitschrift der Gesellschaft für Schleswig-Holsteinische Geschichte, Nordelbingen og Offa med korte mellemrum udsender nye bind i skriftrækken Quellen und Forschungen zur Geschichte Schleswig-Holsteins. Siden 1950 er der i denne skriftrække udsendt ikke mindre end 8 bind. Endvidere udsender selskabet en bibliografi over den nyeste litteratur vedrørende Slesvig og Holsten. Og nu er man også gået i gang med udgivelsen af en stor "Geschichte Schleswig-Holsteins", hvoraf 1. hæfte af 3. bd. er udsendt for nogle måneder siden. Man havde i 1930'erne pábegyndt udgivelsen af en stor slesvig-holstensk historie, men da 1. bind og nogle enkelte hæfter af de følgende bind var udsendt, standsede krigen det videre arbejde. Da man for nogle år siden kunde begynde at tænke pá at fortsætte udgivelsen, var flere af de gamle medarbejdere afgået ved døden, og man besluttede derfor at begynde helt forfra. Det nye værk planlagdes $\mathrm{i}$ 8 bind, til udgiver udpegedes dr. Olaf Klose, medens dr. Fritz Hähnsen og professor Alexander Scharff kom til at danne redaktionsudvalget. En lang række af den slesvig-holstenske historieforsknings betydeligste navne knyttedes til værket som medarbejdere, bl. a. professorerne Carl Schott, Gustav Schwantes, Herbert Jankuhn, Archivdirektor dr. G. E. Hoffmann, dr. H. Kellenbenz og dr. Oswald Hauser. Værket vil senere blive gjort til genstand for en udførlig omtale i Sønderjydske årbøger.

P.K.I.

\section{Statsradiofoniens grundbog: »Grænsen«. 1955192 sider.}

Som baggrund for en række udsendelser indledt med "Huse langs grænsen « ved Sven Alkærsig og Willy Reunert har statsradiofonien udgivet grundbogen "Grænsen " under redaktion af fhv. højskoleforstander Hans Lund, 
professor, dr. phil. Troels Fink og dr. phil. Roar Skovmand. Fhv, kirkeminister Frede Nielsen har før sin død ydet bidrag ved tilrettelæggelsen.

Bogens første tredjedel rummer Hans Lunds skildring af tiden til 1918 , samlet i tre hovedkapitler: den historiske grænse, det nationale gennembrud og Kongeågrænsen og fremmedherredømme. Troels Fink skriver om grænsestriden 1918-20, A. Feilberg Jørgensen behandler i to afsnit med skel ved 1940 udviklingen i Nordslesvig, Johs. Hoffmeyer ligeledes i to afsnit, men med skel ved 1945 udviklingen i Sydslesvig. Bogen bærer præg af at være skrevet af kyndige historikere og giver et godt overblik over udviklingen i grænselandet gennem tiderne. Visse steder har bogens snævre rammer medført en sådan opdyngning af kendsgerninger, at det går ud over læseligheden. Som en kuriositet skal det nævnes, at festlighederne i forbindelse med genforeningen ikke finder omtale; en illustration giver det indtryk, at kongeparret har aflagt et mere tilfældigt besøg på "Folkehjem ". Bogen er forsynet med et godt kortmateriale og en del statistiske oplysninger, der $i$ forbindelse med en god litteraturoversigt, udarbejdet af Aage Bonde, gør den velegnet til studiekredsbrug.

K.F.

\section{Flensburger Tage 1954. Ansprachen und Vortrăge. Herausgegeben von} der Stadt Flensburg. 1955. 101 sider.

Den lille bog rummer alle oplysninger vedrørende det i september 1954 afholdte møde, lige fra de forskellige velkomsttaler til en afsluttende betragtning af mødet ved biblioteksråd, dr. Hans Peter Johannsen, og bringer de forskellige foredrag efter foredragsholdernes manuskript. Det vil utvivlsomt være af særlig interesse for årbøgernes læsere at stifte bekendtskab med de to bidrag til belysning af forholdene i Nordslesvig op mod 1914 , professor, dr. phil. Alexander Scharffs foredrag: Deutsche Ordnungsgedanken zum volklichen Leben in Nordschleswig vor 1914 og professor, dr. phil. Troels Finks foredrag: Der dänische Nordschleswiger, der preußische Landrat, der deutsche Richter vor 1914.

K.F.

\section{K. Edvard Larsen: Den alsiske Landboforening 1855-1955, $114 \mathrm{~s}$.}

Det er efterhånden blevet til en hel række jubilæumsskrifter om foreninger og institutioner i Sønderborg amt, som redaktør $K$. Edv. Larsen har lagt pen og hoved til. Det er det tiltalende ved disse jubilæumsskrifter; at den jubilerende forening eller institution skildres på baggrund af den almindelige nationale, politiske og okonomiske udvikling, hvorved festskrifterne får interesse for en videre kreds. Festskriftet $\mathbf{i}$ anledning af den alsiske landboforenings 100 års bestảen indledes med en kort skildring af landbrugets forhold i Sønderjylland i 1. halvdel af 19. årh. og af det begyn- 
dende organisationsarbejde her $\mathrm{i}$ landsdelen efter kongerigsk mønster. Den alsiske landboforening oprettedes $1855 \mathrm{og}$ tog straks en række af tidens landbrugsfaglige spørgsmål op til indgående drøftelse, bl. a. diskuterede man hjulplov contra svingplov, tærskemaskine, smørfremstilling, dræning og anvendes af kunstgødning. Også offentlige anliggender drøftedes ivrigt på foreningens møder, både før og efter 1864. Et af de spørgsmål, der $\mathrm{i}$ en årrække omkr. 1890 gav anledning til megen meningsudveksling var jernbaneplanerne, hvor en modsætning mellem Sydals og Nordals gjorde sig gældende. Fra fremmedherredømmets tid er det ellers de preussiske myndigheders fremfærd over for foreningens a'rbejde, man især hæfter sig ved. Tiden efter 1920 er behandlet ret kortfattet. Sidst i bogen bringes biografier af foreningens ledende mænd. Som alle K. Edv. Larsens festskrifter fremtræeder også denne bog i et smukt udstyr." Teksten er ledsaget af et smukt udvalg af historiske fotografier.

P.K.I.

\section{J. Raben: Minder fra Nybøl sogn (Fra Als og Sundeved XXXIII), Søn- derborg 1954, $70 \mathrm{~s}$.}

Sønderborg museums flittige inspektør, Jens Raben, har år for år i mere end tre årtier udsendt mindre eller større hæfter i serien „Fra Als og Sundeved«. Snart er det arkæologiske undersøgelser, han publicerer, snart folkloristisk stof, snart fremstillinger byggende på arkivalske undersøgelser og nu og da endogså små kunsthæfter med egne tegninger. En lignende alsidighed træffes ikke hos nogen anden sønderjysk lokalhistoriker og museumsmand $\mathrm{i}$ dag. Det sidste hæfte, nr. 33 i rækken er helliget Nybøl sogn. I en lidt broget blanding bringes her oplysninger om Nybøl herred, om herredstinget, oldtidsminder, kirker, præster, soldatergrave, mindesten og sagn og minder.

P.K.I.

St. St. Blicher: "Vestlig profil af den cimbriske halvø fra Hamborg til Skagen“ er udkommet i ny udgave ved Johs. Nørvig i Hasselbalchs kulturbibliotek.

Denne udgave giver let adgang til at stifte bekendtskab med Blichers stemningsmættede indtryk fra rejsen gennem hertugdømmernes vestegne i 1838

K.F.

\section{Sigurd Schoubye: Folkekunsten på Tonderegnen. Tønder Museums publikationer. 1955. 48 sider.}

Tønder Museum såvel som forfatteren har megen ære af dette hefte, som går i naturlig fortsættelse af de tidligere udsendte hefter: Hollandske 
fliser fra Tønderegnen. 1949, Gamle møbler fra Tønderegnen, 1951. Om engelsk fajance fra Tønderegnen, 1952, Kniplingsindustrien på Tanderegnen 1953 og Gammelt Tøndersølvtøj 1954. Ligesom sine forgængere udmærker dette hefte sig ved mangfoldige og smukke illustrationer, der giver et klart indtryk af Tønderegnens folkekunst gennem de sidste ca. 400 år. Folkekunsten blev først med grundlæggelsen af Dansk Folkemuseum i 1880erne gjort til genstand for indsamling fra museerne; hvad der findes på Tønder Museum er imidlertid indsamlet $i$ lobet af kun godt 30 år, men det foreliggende hefte viser - selv om det medtager prøver fra sável museet i Flensborg, Nationalmuseet og Frilandsmuseet som fra privateje - at det er lykkedes museet $\mathbf{i}$ Tønder at skabe en samling, der giver udtryk for udviklingen på Tønderegnen, stærkt præget som den blandt andet er af bondernes socialt begunstigede stilling i marskegnene. Naturligt optages heftet fortrinsvis af prøver på det hjemlige træskærerarbejde, som forfatteren følger i dets enkelte perioder. Men der redegøres også for bondemaleriet og den egentlige husflidskunst, som forfatteren påviser havde gode kår på egnen. - Heftet er, så vidt vides, det første danske forsøg på at give en topografisk afgrænset oversigt over folkekunst.

K.F.

Klaus Witt: Flensburger Theaterleben vom 16. Jahrhundert bis zur Gegenwart. Schriften der Gesellschaft für Flensburger Stadtgeschichte, Nr. 8, 16 s., ill.

Da der hidtil kun foreligger fă og spredte oplysninger vedrørende det flensborgske teaterliv gennem tiderne, må dr. Klaus Witts lille, men stofmættede skildring hilses med glæde. Dr. Witt tager sit udgangspunkt i den latinske skolekomedie fra omkring 1600, beretter kort om omrejsende teaterselskaber i 1600- og 1700-årene, om det slesvigske hofteaters årlige, langvarige gæstespil, indtil 1795 på rådhuset, derefter i en nyopført teaterbygning, om forsøgene på at starte et eget teaterselskab omkr. 1800, om tivoliteatrene i $1860^{\prime}$ erne og $70^{\prime}$ erne og slutter med omtale af opførelsen af den nye teaterbygning 1894 og det kulturliv, som siden så frodigt har udfoldet sig her.

P.K.I.

Ellen Redlefsen: Flensburg in alten Bildern. Schriften der Gesellschaft für Flensburger Stadtgeschichte, Nr. 9, 195438 s. + 85 tvl.

I indledningen til dette smukke billedhæfte siger dr. Ellen Redlefsen, hvis navn er velkendt fra en række kunsthistoriske bidrag i slesvig-holstenske tidsskrifter, at der er skrevet meget om Flensborgs politiske og økonomiske historie, men kun lidt om byens udseende gennem tiderne. Selv 
om dette sidste ikke holder stik for den nye Flensborg Bys Historie, sả er det dog săre fortjenstfuldt, at et så omfattende udvalg af gamle flensborgske billeder, tegninger, kobberstik og malerier fra tiden 1588 til slutningen af sidste århundrede nu er blevet gjort tilgængeligt for et bredere publikum. I den indledende tekst redegøres der for billedernes tilblivelse og historie, ligesom deres historiske pålidelighed delvis og ganske kort prøves; men generelt gælder dog, at billedmaterialet betragtes og er ordnet ud fra et kunsthistorisk synspunkt. Dette er ikke sagt for forklejne værket, men blot for at pege pá, at det kunstnerisk værdifulde billede som historisk kilde betragtet ikke behøver at have forrangen for dilettantbilledernes minutiøse nøjagtighed - snarere tværtimod, hvilket udgiveren også loyalt vedgår.

P.K.I.

N. V. Due: En Due-række med hustruer, København 1954, 191 s. ill.

Lektor N. V. Due, København, der også er godt kendt her i landsdelen som undervisningsinspektørens faglige medhjælper i fagene fysik og 'kemi, har gennem en lang årrække indsamlet oplysninger vedrørende sin fædreneslægt Due. I et så langt spand af år som fra 1673-1832 har søn fulgt fader som degn i Emmerlev sogn, hvilket vist mả siges at være ret enestående. Medens slægtshistoriske arbejder som oftest bliver en opremsning af navne, fødsels-, vielses- og dodsår, har lektor Due med stor sporsans i arkivernes gemmer fundet materiale til belysning af de åndelige og materielle forhold, hvorunder forfædrene levede. Der findes i bogens optryk af arkivalier værdifulde oplysninger til belysning af skoleforholdene i Emmerlev sogn gennem et par hundrede år, og bogen vil således også have væerdi uden for den snævre slægt.

P.K.I.

Også i svenske tidsskrifter findes nu og da afhandlinger vedrorende sonderjysk historie. I Namn och Bygd, 42. årg., 1954 s. 67-83 har den tyske stednavieforsker, Dr. Wolfgang Laur, skrevet en interessant afhandling om Sliesthorp-Schleswig, Hedeby und Haddeby, hvori han søger at pávise, at Slesvig og Hedeby er en dobbeltbenævnelse for samme lokalitet. Det sidste ord er hermed dog sikkert ikke sagt i denne sag.

P.K.I.

Ligesom det er sket det sidste par ár, vil vi ogsá i år bringe en fortegnelse over den nye litteratur vedrørende sønderjysk historie og topografi, som det ikke har været muligt at omtale nærmere i nærværende halvbind. Enkelte af bøgerne vil dog senere blive mere udførligt omtalt. 
G. E. Hoffmann: Archivschutz und Archivpflege in Schleswig-Holstein. Ein Rückblick. Slesvig 1955, $87 \mathrm{~s}$.

H. Hinz: Vorgeschichte des nordfrisischen Festlandes. Die vor- und frühgeschichtlichen Denkmäler und Funde in Schleswig-Holstein, Bd. III, Wachholtz, Neumünster 1955, 272 s., 84 tvl.

K. W. Struwe: Die Einzelgrabkultur in Schleswig-Holstein und ihre kontinentale Beziehungen. Offa-Bücher, bd. 11, Wachholtz, Neumünster 1955, $216 \mathrm{~s}$.

J. Spanuth: .... und doch: Atlantis enträselt. Union Deutsche Verlagsgesellschaft, Stuttgart 1955, $146 \mathrm{~s}$.

A. Bantelmann: Tofting, eine vorgeschichtliche Werft an der Eidermündung, Offal-Bücher Bd. 13, Wachholtz, Neumünster 1955, $134 \mathrm{~s}$.

Troels Fink: Rids af Sønderjyllands Historie. Vi og vor Fortid, nr. 11, 3. udg. 1955.

R. Pries: Das Geheime Regierungs-Conseil in' Holstein-Gottorf 1716-73. Quellen und Forschungen zur Geschichte Schleswig-Holsteins, Bd. 32, Wachholtz, Neumünster, 1955.

Vort Hjemland Sydslesvig. Red. af Leif Ingvorsen, 1953, $206 \mathrm{s.}$

N. Friis: Slesvigske fodregiment i krig og fred, 1953, $196 \mathrm{~s}$.

Toni Prettenthaler: 90 Jahre Oeversee, 1954, 76 s.

P. Meinhold: Der Katholizismus in Schleswig-Holstein in den letzten Hundert Jahren.

Carl Rodenberg \& Volquart Pauls: Die Anfänge der Christian Albrechts Universität Kiel. Quellen und Forschungen zur Geschichte Schleswig-Holsteins, bd. 31, 1955, $431 \mathrm{~s}$.

Alfred Kamphausen: Die Kirchen Schleswig-Holsteins. H. Bernaerts forlag, Slesvig, 1955, 72 s., 140 tvl.

H. Appuhn: Gotische Plastik in Schleswig-Holstein. Westholsteinische Verlagsanstalt Boyens \& Co., Heide in Holstein, 1955, $60 \mathrm{~s}$.

Lilli Martius: Die schleswig-holsteinische Kunstgeschichte, 1955, ca. 240 s.

Meta Tønder: Madopskrifter siden 1786 fra Tønder og omegn, 1953, 32 s.

Hinrich Kruse: Fürpüster. Das Brandstifterunwesen im Volksmund der Heimat. Bücher der Heimat bd. 5, Wachholtz, Neumünster, $48 \mathrm{~s}$.

Svend Johannsen og C. Jørgensen: Sydslesvig i billeder, 1954, 63 s.

Karl Müller: Die Schlei, eine Tochter der Ostsee, 1954, 133 s.

Reise- und Städteführer: Flensburg und die Ausflugsorte im Grenzland und dem Schleswiger Land, Verlag Alfred Burckardt, Eutin 1955.

Klaus Witt: 150 Jahre Harmonie-Gesellschaft in Flensburg, 1804-1954, $1954,87 \mathrm{~s}$.

E. Lorenzen: Das Kompagnietor, Die Gesellschaft des Flensburger Schiffergelage, 1954, $28 \mathrm{~s}$.

Aus dem Flensburger Museum. Zur 50. Wiederkehr des Eröffnungstages, hrsg. v. d. Museumsleitung, 107 s. 
H. Neumann: Haderslev Amts Museum 5, 1955, $28 \mathrm{~s}$.

Waltraud \& Heinz Siebel: Husum - Tor zu den Halligen. Chr. Wolff, Flensborg, $63 \mathrm{~s}$.

Theodor Voigt: Kunst- und Kulturstätten. Schleswig, Haithabu, Dom, Gottorf. Elmshorn 1954.

Horst Appuhn: Romantisches Schleswig. Chr. Wolff, Flensborg 1954, 64 s.

G. Horstmann: Zwei Jahre meines Lebens. Erinnerungen an Faarhus, 1955 , $79 \mathrm{~s}$.

Heinz Onnasch: Friedrich Wilhelm Lübke. Mensch und Politiker, 1955.

E. O. Wooley: Theodor Storms world in pictures, Bloomington, U.S.A. 1954, 95 s., 300 afb.

P.K.I. 


\section{Noter og nyt}

\section{Professor Otto Scheel:}

\section{PORTRAT AF EN SLESVIGER}

Historikeren Otto Scheels værk er optegnet i de lærdes registre, og der kan enhver se den bedømt. Han begyndte som professor i kirkehistorie i Tübingen. Fra denne tid stammer hans banebrydende værk om Luther, som skaffede ham en kaldelse til Harnacks lærestol, som han afslog til fordel for Kiel. Bortset fra "Die Wikinger", en bog med interessante synspunkter, er hans litterære værk spredte, ofte meget grundige detailstudier, gemt hen i forskellige tidsskrifter. Men mindst lige så vigtig var hans organisation af Hedeby-udgravningerne og hans virke som universitetslærer og leder af Baltisch-Historische Forschungsinstitut.

Mennesket Otto Scheel med dets mange modsigelser kendte færre. Som slesvigsk præstesøn valgte han frivilligt Tyskland som sit fædreland og betegnede sig selv som tysk slesviger med afgjort betoning af navneordet. Tiere end om faderen talte han om moderen, en datter af Andreas Petersen, Dalby. Denne er af danske historikere blevet kaldt den første hjemmetysker, uden rimelig grund, hæevdede Scheel. Moderen blev opdraget hos Herrnhuterne i Christiansfeld og blev dybt grebet af Grundtvig, og hende skyldte han sin varme kærlighed til dansk kultur og en udpræget respekt for andres frie personlighedsudfoldelse. Politisk og religiøst var han liberal af den gamle skole og anerkendte retten til frit valg af nationalitet og til national omsindelse, også i Sydslesvig efter 1945, kunne han end være skeptisk i enkelttilfælde, men han var ikke sikker på, at Nationalstaten var et heldigt Udtryk for nationalitetsideen. Tværtimod betragtede han det som en stor ulykke, at nationalideen sammen med tysk Uberheblichkeit og dansk uforstand sønderslog den danske helstat, der stod hans hjerte nærmest. For den prøjsiske politik i Nordslesvig havde han kun foragt tilovers. Han var ikke kendt som nogen venlig mand. Privat var han uhyre elskværdig, men i polemiken var han en vel hastig og grumme kampglad mand, "men man behøver da ikke at blive uvenner for det! " Mellem ham og flere af de danske historikere, han har krydset klinger med, var der venskab og agtelse. Han deltog voldsomt agitatorisk i kampen om sin fødeby Tønder, men bøjede sig for afgørelsen. Schmidt-Vodder var fra ungdommen til det sidste hans nære ven, "men jeg har aldrig kunnet følge ham i hans krav om en ny afgørelse«. Som slesvigsk sagkyndig ved interne 
forhandlinger om mindretalsskoleforhold i Prøjsen efter 1920 krævede han forgæves en lovgivning, der var mindst lige så frisindet som den danske, som han beundrede. "Havde vi blot danske tilstande her «, sagde han en uge før sin død. I 1924 blev han formand for Schleswig-Holsteinerbund ag forte i denne egenskab en forsonlig politik. I en tale ærede han sit danske, vestslesvigske modersmål, som han var stolt af og talte med forkærlighed, også med sine hjemmetyske venner. Han krævede som en selvfølge af sine studenter, at de skulle kunne læse dansk, hvis de beskæftigede sig med slesvigske forhold, og $\mathrm{i}$ sine sidste ár citerede han $\mathrm{i}$ sine arbejder danske kilder pá originalsproget som en bevidst fordring til læseren. Forholdet til de øvrige slesvigholstenske historikere var ikke altid lige godt. Han blev trængt ud af den store Geschichte Schleswig-Holsteins, og sagde selv, at det var i et anfald af "momentaner Geistesverwirrung", at han var kommet til Kiel fra Tübingen. At han understattede en dansk historikers eget onske om at få tildelt en æresdoktorgrad i Kiel og gennemførte promotionen trods krigen, fik han kun vedkommendes utak for. Under krigen overtog han ledelsen af det tyske institut $\mathrm{i}$ København, efter eget udsagn for at skåne os for en ringere Mand.

Efter 1945 gik der hårdnakkede, ondsindede rygter om, at Scheel var hemmeligt mediem af Sydslesvigsk Forening. Sandheden er, at han forblev tro til det sidste mod sin selvvalgte tyskhed, og selv om han ud fra sin liberale indstilling skarpt afviste enhver tale om kollektiv skyld, bar han som den ansvarsfulde mand han var, skammen og skylden for sit folks handlinger. Men han bevarede også sin stærke, men ikke ukritiske kærlighed til Danmark, en sympatisk dobbelthed, som findes hos andre fremtrædende grænsetyskere, og som gør dem suspekte i deres egen lejr. Scheels sidste offentlige optræden som formand for Landespartei i det ejendommelige makkerskab med Asmus von der Heide, fremkaldte stor bekymring $i$ de rabiate kredse om Flensburger Nachrichten. De vidste, at hans mâl var at tæmme Asmus. Når Landespartei offentlig lyste Sydslesvigsk Vælgerforening i kuld og køn som »landeseigene Partei“ var det Scheels rost, som burde have spredt den danske usikkerhed over for hans handling, så meget mere som vi kendte hans tidligere politik.

Efter eget ønske hviler denne ægte slesviger $\mathbf{i}$ hjertet af Sønderjylland på Hedeby kirkegård.

Poul Kürstein.

\section{Lederskifte på Sønderborg museum.}

Den 1. oktober 1955 er der sket et lederskifte på Sønderborg amts museum, idet inspektør J. Raben er fratrådt og afløst af Jørgen Slettebo.

En sådan begivenhed er en sjældenhed i den danske provinsmuseums- 
verden. Der flyttes ikke meget omkring med museumsfolkene; de fleste bliver gamle i gårde. Hertil kommer for Rabens vedkommende, at han er første generation på museet. Den institution, han nu har forladt, har han set vokse under sine hænder fra den forste spæde begyndelse.

Allerede som helt ung i Christiansfeld og i sine læreår i Haderslev var hans historiske interesse levende og forte ham til at opsøge bekendte oldtidsminder eller voldsteder $i$ omegnen. Vidnesbyrd om disse besøg er flere tegninger og akvareller af oldtidsgrave og desuden en vejleder om gravhøjene i Vedsted, udgivet på tysk i 1907, hvor han også røber sin store interesse for disse mindesmærkers bevaring.

Aret efter er han i Sonderborg, hvor hjemstavnsforeningen for Als og Sundeved og diermed i virkeligheden ogsa museet netop var grundlagt. Først i 1920 fik museet til huse i Sønderborg slot, og fra 1921 var det en institution i offentlig eje. Museet spænder over mange områder, men har dog især samlet sig om oldsager, om folkeminder fra by og amt og om krigsminder fra kampene om Dybbøl. En enestående viden har Raben erhvervet om sin egn, dens folkekultur og historie, men meget af det har han fæstnet $i$ museet og i det tilhørende arkiv. Dette museum blev Rabens livsværk. Her har han udført en samlervirksomhed, som både i omfang og kvalitet står mål med det bedste, der er ydet her i landet, og som med rette blev beundret af en kreds af museumsfolk og historikere, som besøgte museet for et par år siden.

At denne samlervirksomhed navnes først, er sikkert i Rabens ånd. Han har gentagne gange sagt, at han har set det som sin vigtigste opgave at redde, hvad reddes kunne, mens det endnu var tid, og han har dermed bygget en solid grundvold for det videre arbejde i museumsteknisk, pædagogisk og videnskabelig henseende, som et sådant museum giver mulighed for. At Raben nåede så langt, skyldes også det gode forhold til befolkningen, som det lykkedes ham at skabe, og man kan kun onske for hans efterfølger, at han vil blive mødt med den samme tillid, som Raben og hans museum har nydt godt af.

Det var vel nok de jordfaste fortidsminder, som havde Rabens største interesse. Blandt de udgravninger, som han tog initiativet til, kan nævnes fremdragningen af de nu fredede ruiner af Østerholm og udgravningen af vikingebyen Brovold, så vidt vides vort eneste sidestykke til Hedeby. Der er ogsả grund til at nævne, at han i forbindelse med Nationalmuseet udførte et stort arbejde med restaureringen af oldtidsminder, især de store stenaldergravhøje på Als. Man kan kun være glad ved, at Als nu er et af de områder $\mathrm{i}$ landet, der er rigest på seværdigheder af denne art.

Ved siden af det har Raben udfoldet en omfattende skribentvirksomhed. Talrige artikler om historie, folkeminder og forhistorie foreligger fra ham i Sønderjydsk Månedsskrift og andre tidsskrifter. Men især må man nævne den lanje rakke hefter: Fra Als og Sundeved, årboger for historisk sam- 
fund for Als og Sundeved, hvis drivende kraft Raben var. Der findes måske ikke en egn i Danmark, hvor så mange sogne har deres traditionsstof så let ved händen som her.

Alle, der er interesseret i sønderjydsk historie, vil gerne sige museumsinspektør Raben tak for det store arbejde, han har udført, og onske hans efterfølger held og lykke til at føre det videre.

Den ny inspektør i Sønderborg, Jørgen Slettebo, har en alsidig museumsuddannelse bag sig. Han er cand. mag. med historie og geografi som fag og har især interesseret sig for middelalderens historie. Allerede i studietiden har han søgt at uddanne sig indenfor museumsvæsenet, idet han i $1^{1 / 2}$ år har været ansat på montsamlingen, der er en afdeling af Nationalmuseet. Han har deltaget i Nationalmuseets udgravning af Skt. Jørgensbjerg kirke og i tre somre besøgt Tromsø museum i Nordnorge og deltaget i udgravninger af middelalderbopladser der.

Hans Neumann.

Udgiveren af bogen om Uge Sogn, rentier H. P. Jørgensen, Olmervold pr. Tinglev, meddeler , at prisen på sognehistorien er nedsat til kr. 6,00. Bestilling må indsendes direkte til udgiveren. 


\section{Årsberetning og regnskab 1954-55}

\section{Ved Peter Kr. Iversen og Knud Fanø}

Årsmødet afholdtes søndag d. 22. maj på Andersens Hotel i Gram. Formanden fhv. amtslæge, dr. med. H. Lausten-Thomsen bød årsmødets 150 deltagere velkommen og rettede nogle særlige velkomstord til foreningens æresmedlem, fhv. museumsdirektør, dr. phil. M. Mackeprang. Efter at redaktør Morten Kamphøvener, Åbenrå, var valgt til mødets dirigent, aflagde formanden følgende beretning om foreningens arbejde $\mathrm{i}$ det forløbne år:

Siden vi sidst har været samlet til årsmødet, er følgende af vore medlemmer afgået ved døden:

Provst Biering, Dybbøl, overassistent P. B. Børresen, tidl. Åbenrå, rektor P. M. Hertz, tidl. Sønderborg, lærer N. P. Jensen, Svejbæk, Jens Jørgensen, Skodborg, dommer Knud Kortsen, Frederiksberg, Jens Lautrup, Gestrup, fru Mackeprang, København, smedemester P. J. Mamsen, Roost, rektor M. Mogensen, tidl. Åbenrå, grosserer J. C. Møller, Flensborg, gårdejer Hans Petersen, Gram, gårdejer Jørgen Petersen, Sommersted, Peter Petersen, Ringtved, gårdejer Jørgen Skov, Himmark, landsretssagfører, fhv. borgmester Andreas Thulstrup, Haderslev, redaktør C. Willemoes og frue, Ribe.

Jeg udtaler et æret være deres minde.

Medlemstallet har i de senere år holdt sig ret kon'stant, omkring 1160 . Der har været en ret betydelig afgang ved død, som dog igen er udlignet ved nyindmeldelser. Da det nu er 10 år siden, der sidst har været offentliggjort en medlemsfortegnelse i Sønderjydske årbøger, og da der er sket ret betydelige ændringer inden for medlemskredsen, har styrelsen derfor truffet beslutning om, at en ny medlemsfortegnelse skal offentliggøres $\mathbf{i}$ efterårshæftet i år. Manuskriptet hertil er i den sidste tid udarbejdet af kassereren, adjunkt Fanø.

Historisk samfunds vigtigste opgave er fremdeles at udgive Sønderjydske årbøger. Sidste år kunde årbogen udsendes i et omfang på 296 sider, altså lidt mindre end vi mente at kunne love ved sidste årsmøde. I år ser det imidlertid ud til, at vi kan udsende en usædvanlig stor årbog, idet vi takket være et ekstraordinært tilskud regner med, at de to halvbind vil kunne udsendes $\mathrm{i}$ et omfang på tilsammen ca. 400 sider.

I skriftrækken har vi sidste efterår udsendt som nr. $14 \mathrm{~N}$. Black Hansens 
udgave af Åbenrå annaler, en forløber til Åbenrå kirkebog, som vel navnlig personalhistorikere kan have udbytte af. Der er endnu et lille oplag af denne publikation i behold, så de, der måtte have glemt at indsende bestilling på bogen, kan nả at indhente det forsømte. Prisen er for medlemmer $4 \mathrm{kr}$.

Som nr. 15 i skriftrækken udsendes til efterå:et som særtryk af Sønderjydske årbøger arkivar Iversens uddrag af kniplingskræmmer Jens Wullfs dagbøger, og som nr. 16 håber vi meget, ligeledes til efteráret, at kunne udsende 1 . bind af redaktør A. Svenssons levnedsskildring af redaktør Jens Jessen. For nogle år siden bad redaktionsudvalget for Sønderjydske årbøger redaktør Svensson, som i de senere år har varet een af vore flittigste og bedste medarbejdere, skrive en afhandling til årbogerne om Jens Jessen. Redaktør Svensson indvilgede heri; efter en foreløbig orientering $i$ kildematerialet kunde han meddele os, at Jessen-biografien vilde blive en bog, ikke en årbogsafhandling, og senere fik vi meddelelse om, at det blev et værk på to bind. Heraf foreligger 1. del nu i trykfærdigt manuskript, som med klicheer vil fylde op mod 250 tryksider. A. Svensson har gennemarbejdet et meget omfattende trykt og utrykt materiale; med stor sporsans har han fremdraget breve og aktstykker i offentlig og privat eje; ved de mange og omfattende citater herfra vil bogen få stor betydning som kildeskrift til danskhedens historie i fremmedherredømmets tid. Denne velskrevne bogs væsentligste værdi vil imidlertid sikkert komme til at ligge i den redelige og nogterne, men alligevel personlige vurdering af læremesteren Jens Jessens liv og virke. Vi håber, at det vil lykkes os at få dette værk ud i skriftrækken; foreløbig har vi fáet tilsagn om en understøttelse pá $2000 \mathrm{kr}$. fra Dansk Kultursamfund. Vi beder vore medlemmer om fortsat at støtte udgivelsen af vore publikationer i skriftrækken ved at købe dem. Bøgerne udsendes her til priser, der er betydeligt lavere end bogladepriser, og jo flere bøger, vi sælger, des billigere kan vi gøre dem.

Flensborg bys historie, 2. del, som vi også har andel i, men som ikke udsendes i skriftrækken, er nu omsider færdig og udsendes i disse dage til prænummeranterne og boghandlerne. Værket udsendes i fællesskab med Grænseforeningen og med en meget betydelig understøttelse fra Carlsbergfondet. Omfanget er blevet ca. 100 sider større end beregnet, men det herved opståede underskud er dækket af Grænseforeningen, der til gengæld får indtægten af salget. Historisk samfunds medlemmer vil dog fremdeles kunne få værket til favørpris ved bestilling hos kassereren eller direkte hos Grænseforeningen.

Af andre opgaver, som Historisk samfund arbejder med, kan næevnes, at Åbenrå-bogen, til hvis udgivelse Åbenrå kommune har bevilget et betydeligt tilskud, skal være færdig om nogle år; medarbejderne er så småt i gang med arbejdet.

Udgivelsen af fortsættelsen af Refslund Poulsens Minder, der tidligere 
har været omtalt på årsmøderne, er nu sikret, idet der fra forskellige fonds er ydet tilskud til udgivelsen, der besørges af Det danske Forlag.

Sommerudflugterne er blevet populære, så populære, at tilslutningen næsten er ved at være for stor. Men styrelsen er naturligvis kun glad for, at medlemmerne i stigende tal slutter op om disse arrangementer. Det har vist sig, at medlemmerne også gerne betaler en deltagerafgift, således at egnsvandringerne nu i økonomisk henseende hviler i sig selv. Egnsvandringen d. 2. sept. sidste år på Sundeved med museumsdirektør Jørgen Paulsen, Frederiksborg, som leder havde samlet over 400 deltagere, og de fem store busser og mere end 80 privatvogne var til tider ved at skabe trafikknuder på de sundevedske landeveje. Alt afvikledes dog på bedste måde. og forsinkelserne biev kun beskedne. Deltagerne samledes foran Gråsten slot og blev her i den sygemeldte formands fravær budt velkommen af Sv. Anker Hanssen, Nørremølle. Jørgen Paulsen fortalte kyndigt og levende om slottet og dets beboere gennem skiftende tider, og efter at slotskirken var forevist, forte han deltagerne ud til Smol vold. Herfra fortsattes til den interessante Nybøl kirke og til forsamlingshuset i Vester Sottrup, hvor eftermiddagskaffen blev indtaget. Sv. Anker Hanssen og Jørgen Paulsen fortalte her træk af egnens nationalpolitiske historie. Fra Vester Sottrup gik turen videre til Sandbjerg slot og Nørremølle, hvor Sv. Anker Hanssen på sin særegne, levende og underholdende måde berettede om gårdens historie. Turen sluttede ved mindesmærket for maleren Eckersberg ved Blåkrog.

Iøvrigit har Historisk samfund $i$ vinter udadtil ført en rolig og stille tilværelse. Styrelsen har imidlertid ikke ligget på den lade side, idet der har været ført indgående drøftelser om foreningens organisation, om muligheden af oget arbejdsindsats og om inddragning af flere $\mathrm{i}$ det lokalhistoriske arbejde. Overvejelserne resulterede $\mathrm{i}$ det udkast til nye love, som for nogle dage siden sammen med Sønderjydske årbøgers forårshæfte er udsendt til alle medlemmer, og som årsmedet om lidt skal tage stilling til.

Vi har $\mathrm{i}$ ảr som tidligere år modtaget tilskud fra forskellig side. Alle amtsrådene og de fire købstæders byråd støtter os nu årligt med hver 200 kroner. Fra staten modtager vi årligt $1500 \mathrm{kr}$., men vi har nu under henvisning til, at Historisk samfund for Sønderjylland dækker 4 amtsrådskredse og at det som det eneste af samtlige amtshistoriske samfund udgiver to tidsskrifter, søgt undervisningsministeriet om en fordobling af understøttelsen. Gennem redaktør Kamphøvener har vi som situste år modtaget $3000 \mathrm{Kr}$., og til udgivelsen af det omfangsrige efterårshæfte af Sønderjydske årbøger har vi af $\mathrm{H}$. P. Hanssens Mindefond modtaget $2000 \mathrm{kr}$. Også fra Tønder Landmandsbank har vi modtaget et beløb. For disse betydelige tilskud fra offentlige midler og private fonds vil jeg gerne her udtale Historisk samfunds varmeste tak. Uden denne hjæelp vilde vort arbejde langt fra kunne få det omfang, det har i dag, og vi vilde kun kunne gøre os ringe 
hâb om at gennemføre de store opgaver, som endnu ligger og venter forude. Men forudsætningen for, at vi fremdeles kan vente at opnå støtte til vort arbejde er, at vi selv i stedse større tal flokkes om samfundet og at stadigt flere inddrages $\mathrm{i}$ aktivt historisk arbejde.

Dirigenten takkede for den udførlige beretning, hvorefter kassereren, adjunkt Knud Fanø, Tønder, oplæste det reviderede regnskab. Forretningsføreren for Sønderjydsk månedsskrift, viceskoleinspektør W. Christiansen, Tønder, indledede sin beretning med at takke holdere og annoncører. Årsindtægten 1954 havde været 7783,18 kr., medens udgifterne beløb sig til 7131,06 kr. Kassebeholdningen var forøget fra 75,61 kr. til $651,12 \mathrm{kr}$.; gælden var nu på $1646 \mathrm{kr}$. Beretninger og regnskab godkendtes enstemmigt uden drøftelse.

Formanden forelagde derefter det til alle medlemmer udsendte forslag til nye love. Efter nogen drøftelse, hvori deltog forretningsfører A. Korse, Broager, gårdejer Sv. Anker Hanssen, Nørremølie, førstelærer Andersen, V. Sottrup, pastor Malling, Brøns, seminarielærer Frede Hansen, Tønder, professor, dr. phil. Troels Fink, Århus, fuldmægtig Olav Christensen, Haderslev, m. fl. vedtoges de nye love med alle stemmer mod een. Det, der især gav anledning til drøftelse, var det fremtidige forhold mellem Historisk samfund for Als og Sundeved og Historisk samfund for Sønderjylland. På en forespørgsel fra forretningsfører Korse afgaves fra styrelsens side erklæring om, at det ikke med de nye love tilsigtedes en indlemmelse af Historisk samfund for Als og Sundeved som amtskreds under Historisk samfund for Sønderjylland, men en amtskreds under vor forening og Historisk samfund for Als og Sundeved vilde sikkert kunne samarbejde på mange områder. Forhandlinger mellem de to foreningers styrelser vilde kunne afklare Forholdene. På professor Finks Foranledning pointeredes, at vedtagelsen af vedtagterne for amtskredsene kun kunde være forpligtende for Historisk samfunds styrelse, og at den endelige vedtagelse fandt sted på amtskredsenes stiftende møder.

Formanden meddelte herefter, at styrelsen stillede sine mandater til rådighed, for at der kunde vælges styrelse efter de nye love. På styrelsens vegne forelagde han følgende forslag til den nye styrelses sammensætning: H. Lausten Thomsen, Olav Christensen, Werner Christiansen, P. Clausen, Knud Fanø, Troels Fink, Sv. Anker Hanssen, H. Hejselbjerg Paulsen, Joh. Hvidtfeldt, Peter Kr. Iversen, Hans Lund, H. Neumann, H. F. Petersen, Cornelius Schmidt, og Chr. Stenz. Der stilledes ikke andre forslag, og de foreslàede blev derefter af dirigenten erklæret for valgte.

Under eventuelt stillede formanden forslag om, at kontingentet ligesom sidste år fastsattes til 7,50 kr., hvilket vedtoges. Det bifaldtes 
endvidere, at årsmødet 1956 henlæegges til Dybbøl, og at egnsvandringen søges gennemført i egnen omkring Løgumkloster-Draved-Jejsing-Grøngård-Burkal.

Dirigenten sluttede derefter generalforsamlingen.

Efter et fælles kaffebord talte professor, dr. phil. Knud Fabricius om Skåne og Sønderjylland. Årsmødets deltagere spadserede derefter til Gram Slot, hvor museumsinspektør H. Neumann fortalte om slottets historie.

\section{PETER KR. IVERSEN}

Umiddelbart efter årsmødet trådte den nyvalgte styrelse sammen til konstituerende møde. Arbejdet fordeltes således:

Forretningsudvalg: Formand, amtslæge, dr. H. Lausten-Thomsen, Åbenrå, sekretær, arkivar Peter Kr. Iversen, Åbenrå, kasserer, fuldmægtig Olav Christensen, Haderslev.

Foreløbige amtsudvalgsformænd: Haderslev amt, sognepræst $H$. Hejselbjerg Paulsen, Fjelstrup. Sønderborg amt, gårdejer Sv. Anker Hanssen, Nørremølle. Tønder amt, gårdejer Cornelius Schmidt, Døstrup. Åbenrå amt, skoleinspektør P. Clausen, Ảbenrå. Sydslesvig, pastor H. F. Petersen, Satrup.

Redaktionsudvalg for Sønderjydske årbøger: H. Lausten-Thomsen, landsarkivar Johan Hvidtfeldt, Viborg, Peter Kr. Iversen og adjunkt Knud Fanø, Tønder.

Redaktionsudvalg for Sønderjydsk månedsskrift: Museumsinspektør H. Neumann, Haderslev, viceskoleinspektør Chr. Stenz, Flensborg, og viceskoleinspektør Werner Christiansen, Tønder.

Redaktionsudvalg for skriftrækken: Professor, dr. phil. Troels Fink, Århus, forstander Hans Lund, Tanderupgård, Johan Hvidtfeldt og Peter Kr. Iversen.

Som foreningens æresmedlem deltager museumsdirektør, dr, phil. M. Mackeprang, Charlottenlund, i styrelsesmøderne.

PETER KR. IVersen

\section{Årsregnskab og status pr. 31. 12.1954}

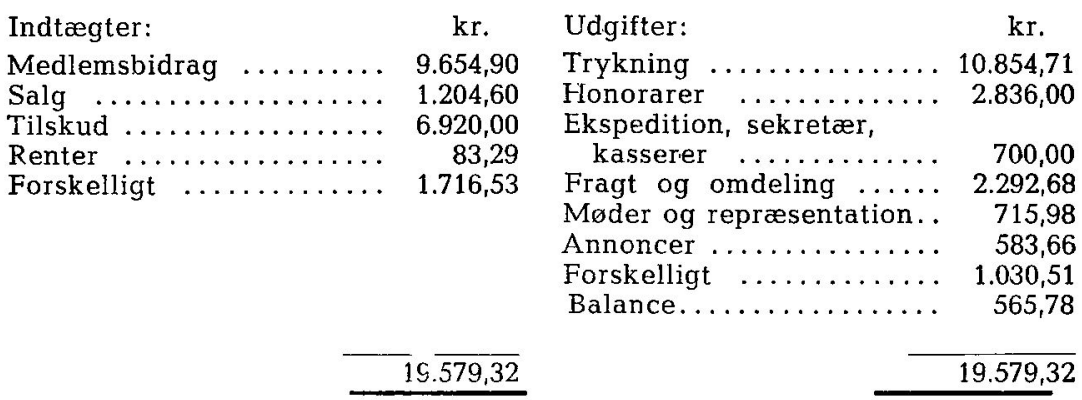


Aktiver: kr. Passiver: kr

$\begin{array}{llll}\text { Post- og bankkonti ..... } & \mathbf{8 7 6 , 4 5} \text { Forudbetalt kontingent- .. } & \mathbf{1 2 7 , 5 0}\end{array}$

Kontant $\ldots \ldots \ldots \ldots \ldots \ldots \quad 10,45$ Regning: Hejmdal . . . . $1.394,45$

Kontingentrestance $\ldots \ldots .204,00$

Udestående for salg ..... 72,00

Saldo ............... 359,05

$1.521,95$

$1.521,95$

Knud Fane

Undertegnede af Historisk Samfund for Sonderjylland valgte revisorer har den 19. og 22. maj revideret ovenstående regnskab, som vi har fundet i orden og overensstemmende med foreliggende bilag. Kassebeholdningen pr. 31. december $1954 \mathrm{kr}$. 886,90 var tilstede. Yderligere er regnskab for 1955 kontrolleret til den 13. maj 1955, og der synes ingen foranledning til indvendinger.

Tender, den 22. maj 1955.

Tønder, den 19. maj 1955.

Jorgen Frank.

Sig. Schoubye. 


\section{LOVE \\ for Historisk samfund for Sonderjylland}

$\S 1$.

Samfundets formål er at vække og nære sansen for sønderjysk historie, især

1) ved udgivelse af Sфnderjydske årbøger, Sønderjydsk månedsskrift og andre skrifter vedrørende Sønderjyllands historie;

2) ved indsamling af arkivalier og andlet skriftligt materiale vedrørende sønderjysk historie;

3) ved at uddove en tilskyndende og vejledende virksomhed over for historisk, særlig lokalhistorisk arbejde;

4) ved at værne om landsdelens historiske mindesmærker;

5) ved at lade holde foredrag om historiske emner, samt ved egnsog byvandrînger.

\section{\& 2.}

Indmeldelse i samfundet sker ved henvendelse til et af styrelsens medlemmer. Medlemsbidraget fastsættes på årsmøderne. S $\phi$ nderjydske årbøger skal med passende mellemrum bringe en medlemsliste, ordnet efter distrikter.

\section{$\S 3$.}

Der søges inden for hver af amtskredsene Åbenrå, Haderslev, Sønderborg og Tønder samt Sydslesvig oprettet amtsudvalg, der sammen med styrelsen og efter retningslinier fastlagte i særlige vedtægter for hver kreds tilrettelægger og leder det lokalhistoriske arbejde i disse. Amtsudvalgenes fungerende formænd er selvskrevne medlemmer af styrelsen.

\section{$\S 4$.}

Samfundet ledes af en styrelse bestående af forretningsudvalg (formand, sekretær og kasserer), redaktionsudvalgene for Sønderjydske årbøger, Sønderjydsk månedsskrift og skriftrækken. Desuden er de fem amtsudvalgsformænd medlemmer af stynelsen. De фvrige, $i$ et antal af mindst 6 medlemmer, vælges på årsmødet, hvoraf almindeligvis højst tre må være bosiddende uden for Sønderjylland. Styrelsesmedlemmerne vælges for tre år ad gangen; genvalg kan finde sted. Styrelsen fordeler selv arbejdet inden for udvalgene blandt de på årsmødet valgte medlemmer. 
$\S 5$.

Tillidsmænd udpeges af amtsudvalgene.

$\S 6$.

Kalenderåret er samfundets regnskabsår. Det årlige regnskab revideres af to for tre år ad gangen valgte revisorer og forelægges i revideret stand til godkendelse på det ordinære årsmødie. $E_{t}$ uddrag af regnskabet meddeles $\mathrm{i}$ årbøgerne.

\section{\$.7.}

Arsmøde for medlemmerne afholdes skiftevis i de forskellige egne. Indkaldelse til mødet sker ved offentlig bekendtg $\varnothing$ relse efter styrelsens nærmere bestemmelse. På mødet gives beretning om samfundets virksomhed i det forløbne år, regniskabet forelægges til godkendelse, og nye valg af styrelsesmedlemmer, eventuelt af revisorer foretages. Endvidere behandles muligt fremkomne forslag fra styrelsen eller fra enkelte medlemmer efter anmeldelse til styrelsens formand minilst 8 dage forud for mødet.

Ekstraordinære medlemsmøder indkaldes, når styrelsen finder anledning dertil, eller når mindst 50 medlemmer stiller skriftligt forlangende derom. På ånsmødierne træffes afgørelse ved simpel stemmeflerhed; til vedtagelse af ændringer i vedtægterne kræves dog enten tre fjerdedel af det afgivne antal stemmer, eller at ændringerne vedtages med simpel stemmeflerhed på to efter hinanden følgende medlemsmøder.

$\S 8$.

Beslutning om samfundets opløsning kan kun tages på et $\mathbf{i}$ henhold til \& 7 sammenkaldt ordinært eller ekstraordinært medlemsmøde, på hvilket forslaget om opldsning vedtages med mindst to trediedel af de afgivne stemmer. Om denne sag kan stemme afgives enten personligt eller ved skriftlig fuldmagt til et mødende medlem. Ved opløsningen skal samfundets arkiv overladies til det $s \propto$ nderjyske landsarkiv i Åbenrå. Over en eventuel kassebeholdning ved opløsning tager det afsluttende medlemsmøde beslutning.

$\S 9$.

Forhold, som ikke er omtalt i disse love, afgøres af styrelsen.

Veditaget på årsmødet den 22. maj 1955. 


\section{VEDTÆGTER \\ for \\ amtskreds' bistoriske Samfund \\ under Historisk samfund for Sonderjylland \\ Udkast godkendt af arsmodet den 22. - 5. 1955}

$\S 1$.

Medlemmer er samtlige medlemmer af Historisk samfund for S $\varnothing$ derjylland, der har deres bopæl inden for

amt.

$\S 2$.

Amtskredsen afholder generalforsamling een gang om året. Her vælges et amtsudvalg på 3-5 mand for tre år ad gangen. Udvalgsmedlemmerne afgår paa skift, første gang ved lodtrækning. Udvalget konstituerer sig med formand, sekretær og kasserer.

\$3.

Amtsudvalget varetager i samråd og i samarbejde med styrelsen for Historisk samfund for Sønderjylland dettes stedlige opgaver i amt. Det vil sфge at vække og nære den historiske sans, især ved lokalhistoriske foredrag, om muligt i samarbejde med stedlige foredragsforeninger, ved at arrangere egns- og byvandringer og ved at $\$ \emptyset$ ge oprettet sognehistoriske grupper.

$\S 4$.

Amtsudvalgets fungerende formand er selvskrevet medlem af styrelsen for Historisk samfund for Sønderjylland.

\section{$\S 5$.}

Amtsudvalget udpeger på Historisk samfunds vegne tillidsmænd, som regel een i hvert sogn.

$\$ 6$.

Til dækning af omkostningerne ved amtskredsens arbejde stilles et bel $\varnothing \mathbf{b}$ til rådighed fra Historisk samfund for Sønderjylland. Amtskredsen kan ikke opkræve særligt kontingent og kan ikke uden samrâd med styrelsen modtage offentlige tilskud.

$\S 7$.

Inden 1. maj indsendes en beretning over arbejdet $i$ det forløbne år til Historisk samfunds sekretær og en regnskabsoversigt til kassereren.

§ 8.

Disse vedtægter kan kun ændres med billigelse af styrelsen for $\mathrm{Hi}-$ storisk samfund for Sønderjylland. 


\section{Medlemsfortegnelse}

Efterfølgende medlemsliste for Historisk Samfund for Sønderjylland er ordnet topografisk. Inden for hvert amt er medlemmerne i købstæderne anbragt først, derefter følger flækker og sogne i alfabetisk rækkefølge. Efter de nordslesvigske amter kommer medlemmerne i Sydslesvig, i Storkøbenhavn, i det øvrige land og i udlandet. I København anføres den nøjagtige adresse, uden for København kun byens navn.

Man har fra bestyrelsens side bestræbt sig for at få fortegnelsen så fuldstændig og rigtig som muligt, og den er derfor i manuskript gennemgået af alle bestyrelsens medlemmer. Ofte er det således, at hvis et medlem afgår ved døden, bliver hans enke eller børn ved med at være medlem. I sådanne tilfælde får ekspeditionen sjældent meddelelse om dødsfaldet, hvorfor det trods den største påpasselighed næppe helt har kunnet undgås, at der på fortegnelsen opføres enkelte afdøde medlemmer. På den anden side har dette forhold medført, at medlemslisten ikke er fuldstændig, da vi har udeladt navnene på de medlemmer, som vi vidste var døde, selv om de efterladte har fortsat medlemsskabet. Når der ses bort fra disse tilfælde, havde Historisk Samfund pr. 15. 9. 551210 medlemmer, der fordeler sig sảledes på landets enkelte dele:

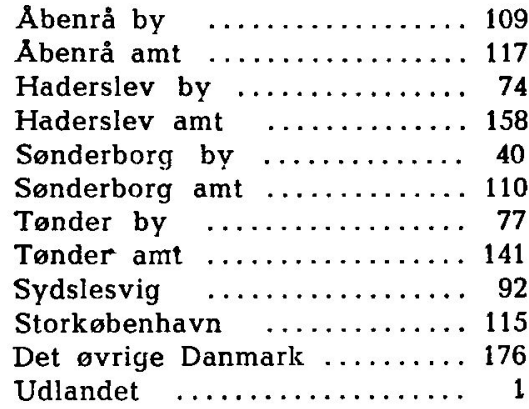

\section{Abenrå amt}

Abenrå by:

Auring, Gustav, overbibliotekar

Beck, P., lektor

Beeck, C. J., overportør

Bentsen, J., fuldmægtig
Beyer, A., øjenlæge

Black-Hansen, N., rentier

Boeck, Holger, overretssagfører

Bojesen, Harald Bo, boghandler

Bruun, P. Groth, sekretær

Caspersen, Jes, kontorchef

Christensen, H. P., politifuldmægtig

Christensen, J., kommunaldirektør

Christiansen, Jes, direktør

Clausen, P., skoleinspektør

Demuth, Chr., fhv. forstander

Enemark, Kristine, kommuneass.

Erichisen, N., bankdirektør

Fallesen, Aksel V., tandlæge

Fink, Holger, fhv. borgmester

Fink, Jep, arkitekt

Flade, Karl, ingeniør

Frank, Peter, gårdejer

Frost, Jens, museumsinspektor 
Gade, Carsten, lærer

Gribsvad, Frode, landsarkivar

Gundestrup, S. E., stadsingeniør

Hahnemann, Fr., lektor

Hammerich, C. L. V., landsretssagfører

Handelsbanken

Hansen, Asmus, branddirektør

Hansen, Hans, konsulent, fhv. kreditforeningsdirektør

Hansen, Jørgen M., konsul

Hansen, Lorenz jun., købmand

Hansen, Margrethe, kontorist

Hansen, S. P., stadsskoleinspektør

Hanssen, Bjørn, redaktør

Iversen, Peter Kr., arkivar

Jacobsen, Chr., gartner

Jacobsen, Holger, overassistent

Jacobsen, Mathias, læge, dr. med.

Jacobsen, Marie, frk.

Jacobsen, Th., farver

Jensen, Johs., statskonsulent

Jensen, Karen Skipper, bibliotekar

Jensen, Nicolai, bygmester

Jensen, Rigmor, lærerinde

Jepsen, Jens, forpagter

Jepsen, P. M., kommunelærer

Jessen, Carsten, fabriksinspektør

Jessen, Peter, købmand

Johansen, Fr., direktør

Johansen, Hans, landsretssagfører

Juul-Jørgensen, G., lektor

Kamphøvener, Morten, redaktør

Kiil, Jens, civilingeniør

Kirchhof, Marie Elisabeth, viceskoleinspektør

Kjeldsen, Ernst P., kriminalbetjent

Kjeldsen, Th., lektor

Klinkby, Jens V., lektor

Kristensen, Dagny, overlærer

Kristensen, Saren, fhv. overlærer

Landsarkivet

Landsbiblioteket

Laursen, Aage, adjunkt

Lausten-Thomsen, H., amtslæge dr. med.

Levinsen, N., fhv. dommer

Lildholdt, $H$, bankdirektør
Lindballe, Julie, lektor

Ludvigsen, Carl Johs., pastor emer.

Madsen, apoteker, fru

Mandrup-Andersen, Poul, landsretssagfører

Michelsen, Anne Helene, aut. fysioterapeut og sygegymnast.

Michelsen, Karen, Kolstrup

Michelsen, Mads, amtslæge, dr.med.

Moos, Holger, lektor

Moos, P. H., pastor emer.

Moller, Mimi, fru

Mørch, Fr., socialinspektør

Nielsen, Dagmar Joh., fru

Nielsen, E., amtsforvalter

Nielsen, Margr., journalist

Nielsen, Søren Bjerregaard, lærer

Nygaard, H., mejeribestyrer

Olsen, Helga, amtsfuldmægtig

Ostenfeld, Svend, amtslæge dr. med.

Pedersen, Ingemann, lektor

Petersen, Alfred, overlærer

Petersen, Peter, smedemester

Præstholm, Anders Clod, bibliotekar

Quistgaard, A. W., pastor emer.

Ramhøj, J., fhv, stadsingeniør

Rasmussen, Henrik, viceskoleinsp.

Rode, C. C., guldsmed

Rosenstand, Gregers, landsretssagfører

Samuelsen, Marie, husbestyrerinde

Schaumburg-Christensen, N., politimester

Schlüter, H., sparekassebogholder

Simonsen, H. Holdt, provisor, cand. pharm.

Statsskolens bibliotek

Stave, Jørgén, lærer

Serensen, Osvald, prokurist

Sørensen, S. M., arkitekt

Thomsen, Kr. Refslund, fhv. amt-

mand, kammerherre

Thomsen, Marie, enkefru

Thorsmark, Valdemar, urmager

Tofft, Helga, fru

Tolstrup, E. A., fhv. postkontroller

Trumpf, Heine, kommuneassistent

Ølgaard, A., sparekassedirektør 
Bedsted sogn:

Biblioteket, Bedsted

\section{Bjolderup sogn:}

Bertelsen, Hans, lærer, Rebbol Bjolderup sogneråd

Hanssen, P. Chr., gårdejer, Nygård Holdt, Jacob, lærer, Bjolderup Jensen, Laust, gårdejer, Gåskær Jørgensen, Andr., sognefoged, Raved Simonsen, Valdemar, lærer, Bolderslev

Bov sogn:

Biblioteket

Bov sogneråd

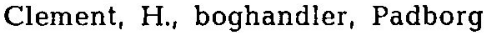

Dahlkild, P. A., dyrlage, Padborg

Due, P. N., læge, Padborg

Gregersen, Karsten M., gårdejer, Frøslev

Harritsøe, Axel, sognepræst, Bov

Jepsen, N. A., toldkontrollør, Padborg

Jargensen, $M$. C. Feifer, toldkontrollør, Kruså

Knudsen, Ebbe, lærer, Vejbæk

Kock, H. Chr., overtoldassistent, Padborg

Larsen, Karl, overtoldbetjent, Bov

Lauritzen, M., pastor emer., Padborg

Lorenzen, Hans, læge, Bov

Morell-Jensen, tandlæge, Padborg

Schmidt, Hans, gårdejer, Kollund

Skovrup, Ejnar, forstander, Sønderhav

Sørensen, R. P., kommunelærer, Buskhøj

Tegewaldt, førstelærer, Bov

Wortmann, Andreas, arb., Bov Mark

Egvad sogn:

Eriksen, Kristine, lærerinde, Hønkys

Fink, Knud, gårdejer, Nr. Hostrup

Hansen, Jacob, sognefoged, Øbening

Nissen, fru, Tingbjerggård

Ensted sogn:

Budsted, Elmer, uddeler, Stubbæk

Biblioteket, Røllum skole
Skau, Hans, sognefoged, Lillehave

Staugaard, Fester, gårdejer, Torp

Felsted sogn:

Biblioteket, Felstedskov

Iversen, Helene, fru, Svejrup

Lassen, Hans, gărdejer, Tastegård

Petersen, H., lærer, Felstedgård

Skovgaard-Petersen, H., skoleelev,

Felsted

\section{Gråsten sogn:}

Biblioteket

Bjerre, politimester

Grăsten Bank A'S

Grảsten kommunale skole

Gråsten sogneråd

Hansen, Hans, forstander

Hvidt, C. V., sognepræst

Jensen, Gerhard, dommer

Kjems, Sven, landsretssagfører

Kræmer, Jens, bankkasserer

Lauridsen, L., forstander

Warncke, Anna, lærerinde

Hellevad sogn:

Bibiiotcket, Hellevad

Grau, P. O., lærer, Hellevad

Hansen, P. A., revisor, Hellevad

Hansen, Peter, førstelærer, Hellevad

Høier, Peter, lærer, Klovtoft

Petersen, E. O. J., lærer, Klovtoft

Rafaelsen, Johannes, lærer,

Hellevad

Stephansen, W., sognepræst, Hellevad

Hjordkær sogn:

Bøgh, Chr., sognefoged, Hjordkær

Haugaard, M., lærer, Hjordkær

Hejsel, Andreas, landmand, Kassogård

Hjordkær sognerảd

Jessen, Heinr., gårdejer, Nybol

Holbol sogn:

Biblioteket, Hokkerup

Jepsen, Chr., lærer, Holbøl

Vollsen, Henning, gårdejer, Øster

Gejl 
Kliplev sogn:

Biblioteket, Sirgård skole

Hansen, Chr., førstelærer, Kliplev

Kliplev sogneråd

Philipsen, Kr., gårdejer, Lundtoft

Zachariassen, sognepræst, Kliplev

\section{Løjt sogn:}

Biblioteket, Løjt Kirkeby

Gammelgaard, A., førstelærer, Barsmark

Hansen, Karl, gårdejer, Dybvighoved

Hartmann, P. H. Boye, landsretssagfører, Løjt Kirkeby

Ipland, Maren, lærerinde, Barsø

Juhler, Ed., pastor emer., Løjt Kloster

Larsen, Anders, karetmager, Skovby

Lauesen, Harald, maler, Bodum

Toftkær, Arild, gårdejer, Stolliggård

Warming, Jørgen, gårdejer, Stollig

Rinkenæs sogn:

Bartholdy, Chr., oberstløjtnant, Rinkenæs

Beyer, Fr., provst, Rinkenæs

Haarder, Hans, forstander, Rønshoved

Nørgaard, Kr., forstander, Årsbjerg

Rinkenæs sogneråd

Rise sogn:

Adolphsen, Chr., tømrermester, Rise

Ipland, Ernst, gårdejer, Søst

Jepsen, Christine, Iærerinde, Rødekro

Jespersen, J., gårdejer, Rødekro

Keller, A. B., overportør, Rødekro

Larsen, N., kommunesekretær, Rødekro

Lassen, P., glarmester, Rise

Matthiesen, Carl, skoleleder, Rødekro

Møller, J. P., proprietær, Søstgård

Ratzer, A., lærer, Rise-Hjarup

Riishøjgaard, Sigfred, sognepræst, Rise

Wichmann, C. W., kontorassistent, Rødekro
Uge sogn:

Jørgensen, H. P., rentier, Olmersvold

Varnæs sogn:

Biblioteket, Bovrup

Biblioteket, Varnæs

Bladt, Jørgen, gårdejer, Varnæs Grav

Bunde, Peter, gårdejer, Bovrup

Hanssen, Hans Peter, dyrlæge, Bovrup

Lauersen, Jens Chr., kontrolassistent, Bovrup

Lyck, Hans, fhv, amtsrådsmedlem, Varnæs

Schmidt, Hans J., gårdejer, Flyvbjerggård, Varnæs

Schrøder, Urban, sognepræst, Varnæs

Oster Logum sogn:

Callesien, Nis H., gårdejer, Lerskov

Callo, Mads, gårdejer, Genner

Holdt, Jes M., lærer, Rugbjerg

Johansen, Bendiks, gårdejer,

Nr. Hjarup

Kristensen, Jens, lærer, Østerløgum

Pedersen, Peter, sognepræst, Østerløgum

Tiedemann, Senius, Stenhøj

pr. Hovslund

\section{Haderslev amt}

Haderslev by:

Abild, I., ingeniør

Agerschou, E. Kruse, afdelingsleder

Algreen-Petersen, boghandler

Andresen, Sigurd, kriminaldommer

Biblioteket

Bork, N. J., politifuldmægtig

Braae, F., idrætsinspektør

Bruhn, Daniel, købmand

Callø, P. A., direktør

Christensen, Olav, fuldmægtig

Christiansen, Christy, fru

Christiansen, Henry, tømmerhandler

Christiansen, Poul, grosserer

Davidsen, D., tingbogfører

Dueholm, P., seminarielærer

Ebbesen, Niels, glarmester

Fahrendorff, Valdemar, urmager 
Favrholdt, M., lektor

Flensmark, A. F., stiftsprovst

Gadeberg, P., pastor emer.

Haderslev amtsmuseum

Hansen, H. L., grosserer

Hansen, Harry, overlæge

Hansen, M., tandlæge

Firmaet Michael Hansen

Haslund, P., statsaut. revisor

Heinskou, Knud, læge

Henningsen, Aage, guldsmed

Hjorteapoteket

Hajberg, Joh. L., fuldmægtig

Jacobsen, Andreas, museumsbetjent

Jacobsen, N. H., rektor, dr. phil.

Jensen, Th., driftsbestyrer

Jensen, Th., komm, undersøger

Jørgensen, Andreas Tørring, magistratsfuldmægtig

Jørgensen, Fred., prokurist

Karlsson, Henry, lektor

Katedralskolens bibliotek

Lauritzen, Vald., skoleinspektør

Lauritzen, L. B., amtslæge

Lindhardt, Th., landinspektør

Lund, Chr., overlærer

Michael, C., børnehaveleder

Michael, Marie, frk.

Mosbech, Aage, amtslandinspektor

Møller, H. C., boghandler

Møller, P., pens. lærer

Neumann, Hans, museumsinspektør

Nielsen, Johs., boghandler

Nielsen, Palle, seminarielærer

Noack, C., biskop

Olrik, Knud, lektor

Petersen, Holger, viceskoleinspektør

Pontoppidan Thyssen, fhv. stiftsprovst

Poulsen, Ingrid, fru, danselærerinde

Reumert, Eigil, lærer

Roust, Th., amtsskolekonsulent

Rudbeck, Fr., rejseinspektør

Ruhwald, Erik, læge

Schmidt, P. Th., pedel

Schroeder, Erling, overlæge, dr. med.

Schrøder, L. J., postkontrollør

Schultz, J., læge, dr. med.
Sorgenfri, Jørgen, snedkermester

Søchting, A., redaktør

Sørensen, Alma, jordemoder

Thomsen, Andr., viceskoleinspektør

Thomsen, N. Th., redaktør

Thomsen, Sophus, direktør

Truelsen, P., kontorassistent

Vig, Chr., lærer

Wildfang, J., stiftskasserer

Wind, J., bogtrykker

Østergaard, M. K., lektor

Agerskov sogn:

Junker, Alfred, slagtermester, Agerskov

Lautrup, L. H., gårdejer, Vellerup

Lund, Kr., gårdejer ,Gestrup

Nielsen, Peder, gårdejer, Rangstrup

Ottsen, Jes, mejeribestyrer, Rangstrup

Petersen, Andreas, købmand, Rangstrup

Poulsen, Martin Refslund, gårdejer, Bovlund

Refslund, N. H., gårdejer, Bovlund

Refslund, Solvejg, Bovlund

Reinholdt, Chr. Jessen, gårdejer,

Oksgård

Rolskov, E., lærer, Gestrup

Aller sogn:

Boesen, gårdejer, Stubbom

Boesen, Erik, gårdejer, Stubbom

Bevtoft sogn:

Mortensen, Anders, Strandelhjørn

Nissen, Peter Jessen, gårdejer,

Strandelhjorn

Sandholdt, M., bygmester, Bevtoft

Skov, A. L., rentier, Bevtoft

Bjerning sogn:

Bjerning sogneråd

Branderup sogn:

Abrahamsen, Eskild, aftægtsmand,

Branderup

Biblioteket, Branderup

Boisen, Thomas, købmand, Brande. rup

Rasmussen, Th., mejeribestyrer, Branderup 
Thomsen, Jakob, gårdejer, sognerådsformand, Branderup

Christiansfeld flække:

Hansen, Jac. H., dyrlæge, Christiansfeld

Jacobsen, Nis, installatør, Christiansfeld

Krog, Hans, rentier, Christiansfeld

Madsen, Johan, borgmester, Christiansfeld

Sparre, Peter, kæmner, Christiansfeld

Fjelstrup sogn:

Clausen, Chr., førstelærer, Fjelstrup

Hansen, Jes, gårdejer, Fjelstrup

Møller, Rasmus, proprietær, Toftegård, Fjelstrup

Paulsen, Hejselbjerg, H., sognepræst, Fjelstrup

Thomsen, Jørgen, gårdejer, Knud

Fole sogn:

Ehrenreich, Aage, førstelærer, Fole

Filtenborg, P., provst, Fole

Gram sogn:

Biblioteket, Gram

Fries, Lorenz, Gram Maskinværksted

Friis, Nis, gårdejer, St. Sandet

Frisk, Anders, snedkermester, Gram

Hagen, Søren, førstelærer, Tiset

Madsen, Mads Peter, gårdejer,

Tiset Østermark

Mathiesen, Hans, kredsrevisor, Gram

Skjærlund, Carl, vejassistent, Gram

Timmermann, købmand, Gram

Weber, Peter, vognmand, Gram

Halk sogn:

Biblioteket, Hejsager skole

Eriksen, Erik, gårdejer, Halk

Hjerndrup sogn:

Hansen, Peter, gårdejer, Hjerndrup

Hjerling sogn:

Friis, Hans, lærer, Hjerting

Hansen, Ejnar, gårdejer, Bjærnekær
Hoplrup sogn:

Biblioteket, Hoptrup

Christensen, C. M. lærer, Djernæs

Lauritzen, P. H., forstander, Hoptrup

Hygum sogn:

Fokdal, Hans N., pens, lærer,

Fredsted

Fredslund, Ejnar F., gårdejer,

Sdr. Hygum

Hjuler, P. A., gårdejer, Sdr. Hygum

Simonsen, Christen, handelsmand,

Sdr. Hygum

Jels sogn:

Biblioteket, Jels

Grønbjerg, Jens R. M., førstelærer,

Grønnebak

Ravn, H., læge, Jels

Jægerup sogn:

Biblioteket, Jægerup

Lintrup sogn:

Jensen, H. S., gårdejer, Tornumgård

Magstrup sogn:

Dalberg, Ernst, sognepræst, Magstrup

Petersen, Jens, vognmand, Magstrup Petersen, P., køomand, Magstrup

Nustrup sogn:

Ebbesen, Poul J., sognepræst, St. Nustrup

Gram, J., gắrdejer, folketingsmand, Ankergård

Iversen, Marius, gårdejer,

St. Nustrup

Sørensen, H. M., lærer, St. Nustrup

Østergaard, J. H., sen., gårdejer,

Gabøl

Rødding sogn:

Biblioteket, Rødding

Fink, Haakon, gårdejer, Brændstrup

Høyer, Minna, fru, Rødding

Larsen, Axel, læge, Rødding

Lyck, P., direktør, Redding

Madsen, Hans, redaktør, Rødding

Mandøe, Asbjørn, højskolelærer, cand. mag., Rødding 
Nissen, Georg, landbrugskonsulent, Rødding

Pedersen, Arne Fog, højskoleforstander, Rødding

Pedersen, Karen, lærerinde, Rødding

Rødding Højskoles bibliotek

Staurup, P. P., Radding

Svendsen, Kr., fhv. frimenighedspræst, Rødding

Sørensen, S. A., snedkermester, Redding

Østergaard, Jakob, kommissionær, Rødding

Skodborg sogn:

Biblioteket, Skodborg

Hansen, Kresten, gårdejer, Højvang

Hollensen, Andr., købmand, Skodborg

Hollensen, Jørgen, sognerådsformand, gårdejer, Skodborg

Larsen, Viggo, gårdejer, Skodborg

Nielsen, Sigfred, bogholder, Skodborg

Otte, Peter Petersen, forpagter, Gejlager

Schmidt, Aage, gårdejer, Fårkrog

Schmidt, Jens Graasbøl, landmand, Højgård

\section{Skrave sogn:}

Dall, Christen H., Københoved

Ferslev, M. F. malermester, Københoved

Gram, Kate, Kobenhoved

Kloppenborg Skrumsager, gårdejer, Københoved

Københoved bogsamling

Mathiesen, H. J., mejeribestyrer, Skrave

Skov, Hemming, landmand, Københoved

Skrydstrup sugn:

Laursen, Agnethe, lærerinde, Skrydstrup

Ludvigsen, Hans, gårdejer, Hørlyck

Madsen, Chresten, sekretær, Skrydstrup

Sognebiblioteket, Skrydstrup

Starup sogn:

Outzen, Karl, gårdejer, Vandling

Sommersted sogn:

Michelsen, R., dyrlæge, Sommersted

Møller-Nielsen, P., forstelærer, Sommersted

Schmidt, Johan, gårdejer, Kastvrå

Stepping sogn:

Nissen, Martin, sognepræst, Stepping

Toftlund sogn:

Hansen, Eskild, gårdejer, Stavninggaard, Toftlund

Johansen, Ejlif, boghandler, Toftlund

Thyssen. Peter, gårdejer, Gravlund

Tyrstrup sogn:

Bancke, Viggo, lærer, Tyrstrup

Fink, Hans, gårdejer, Skovrup

Paulsen, Johs., gårdejer, Gammelgârd

Vedsted sogn:

Hansen, Jakob, bestyrer.

Over Jerstal

Hansen, Laurids, gårdejer, Arnitlund

Vilstrup sogn:

Biblioteket, Sdr. Vilstrup

Gade, Paul Ø., sognepræst, Sdr. Vilstrup

Kloppenborg Skrumsager, gảrdejer, Kanekær

Neumann, Marcus, gårdejer, Sdr. Vilstrup

Vilstrup sognerảd

Vojens sogn:

Aalling, J. Jensen, arkivar, Vojens

Biblioteket, Vojens

Christensen, B., ingeniør, Vojens

Hagelse, E., forstander, Vojens

Jørgensen, Harald T., lærer, Vojens

Pedersen, Knud Schmidt, Vojensgård

Poulsen, uddeler, Vojens

Schmidt, L. O., boghandler, Vojens 
Osby sogn:

Biblioteket, Øsby

Sørensen, Simeon, gårdejer, Hajstrup

Oster Lindet sogn:

Biblioteket, Øster Lindet

Leerskov, Hans, forpagter, Terp

Skau, J., forpagter, Nygård

\section{Sønderborg amt}

Senderborg by:

Beck, Hans, turistchef

Biering, provstinde

Brock, pens. stationsmester

Centralbiblioteket

Christensen, Helge Møller, kommunelærer

Ewald, dr., tandlæge

Gregersen, E. V., amtslandinspektør

Gregersen, Gudrun, adjunkt

Hansen, J., pastor emer.

Hansen, Julius, prokurist

Jacobsen, Chr. W., ostegrosserer

Jacobsen, P., bankdirektør

Jensen, A. Egeberg, rektor

Kock, J. H. købmand

Krogh, Hans, viceskoleinspektør

Larsen, Kai Edvard, redaktør

Lausten-Thomsen, Gert, læge

Linnet, Sven, læge

Lodbjerg, O., stationsleder

Meyling, M., arkitekt

Miang, H., landsretssagfører, dr. jur.

Mynborg, Poul, landsretssagfører

Møller, Niels, dr. phil.

Nielsen, N. P. pastor emer.

Novrup, Hans, amtsskolekonsulent

Nørhald, M., landsretssagfører

Petersen, Hans, sagfører

Petersen, Viggo, lektor

Raben, J., museumsinspektør

Rasmussen, J. N., skoleinspektør

Rasmussen, Poul Winkel, cand. pharm.

Ræder, M. O., fhv. postmester

Schack, S. A., aberstløjtnant

Schmidt, $P$., restauratør

Sorring, J. R. N., overbibliotekar

Statsskolens bibliotek
Sønderborg magistrat

Wernich, N., læge dr. med.

Winther, Aage, dyrlæge

Wisse, Svend E., kontorchef

Asserballe sogn:

Brummer, Tage, sognepræst, Asserballe

Christensen, Ernst, gårdejer, Asserballe

Pedersen, Marie Bek, lærerinde, Asserballeskov

Simonsen, Christine, lærerinde, Asserballe

Vogt, Chr., gårdejer, Asserballeskov

Augustenborg flække:

Biblioteket, Augustenborg

Dahl, Holger, kæmner, Augustenborg

Jensen, Gregers, læge, Augustenborg

Broager sogn:

Dirksen, H., dr. med., Broager

Hansen, Reinholdt, lærer, Brunsnæs

Hofgaard-Møller, A., sparekassedirektør, Broager

Hollensen, Svend, gårdejer, Mølmark

Jensen, Knud Nordmann, teglværksejer, Cathrinesminde

Korse, Aug. forretningsfører, Broager

Kyster, Johs., sognepræst, Broager

Moos, Ellen, boghandler, Broager

Petersen, Chr. jun., forpagter,

Mølmark

Rasmussen, Sv, Riis, lærer, Skelde

Rohden, Heinrich Fr., landpoliti-

betjent, Broager

Rohleder $H$., provst, Broager

Tychsen, Peter, gårdejer,

Krammark

Dybbøl sogn:

Bang, H. O. C., sognepræst, Dybbel

Biblioteket, Dybbøl

Ruge, Emil, keramiker, Dybbøl

Egen sogn:

Biblioteket, Egen

Frandsen, Jørgen, sognefoged, Guderup 
Hagenbjerg sogn:

Andreasen, Hans, Havnbjerg

Christensen, Claus, gårdejer,

Lavensby

Clausen, Hans, gårdejer, Havnbjerg

Jakobsen, Andreas, gårdejer,

Lavensby

Jørgensen, Jørgen, gårdejer, Lavensby

Schmidt, Andreas, sognefoged, Havnbjerg

Skov, Christian, gårdejer, Lavensby

Sørensen, Alfred, gårdejer, Lavensby

Horup sogn:

Biblioteket, Hørup

Danielsen, Johs., hotelejer, Høruphav

Hell, Peter, husmand, Lambjerg

Jessen, $H$. H., Peberbjerg

Kaad, Andreas, sognefoged, Mindebjerg

Kock, Chresten, gårdejer, Tornemosegård, Kirkehørup

Petersen, Anton, Lambjerg, Kirkehørup

Speggers, Chresten, Miang

Kegnæes sogn:

Andreasen, Georg, lærer, Sønderby

Biblioteket, Kegnæs

Jepsen, Riis, lærer, Østerby

Ketting sogn:

Biblioteket, Ketting

Lysabild sogn:

Andersen, Nicolai, gårdejer, Fjelby

Hansen, H. J., gårdejer, Lysabildskov

Jensen, Christian, gårdejer, Skovby

Madsen, H. C., sognepræst, Lysabild

Rasmussen, J., lærer, Lysabildskov

Nordborg flække og sogn:

Albrecht, W., bagermester, Holm

Biblioteket, Nordborg

Blichfeld, sognepræst, Nordborg

Blomgren, P., bankbestyrer, Nordborg
Clausen, H. Chr. From, gårdejer, Broballe

Diedrichsen, Peter, forpagter, Lunden

Eriksen, Christen, gårdejer, Broballe Frank, Jørgen, konsulent, Nordborg Hansen, Jes, lærer, Holm

Holm sogneråd

Jensen, R. M., førstelærer, Holm

Petersen, Albert, fhv. borgmester, Nordborg

Skov, Helene, lotterikollektrice, Nordborg

Skov, Niels købmand, Nordborg

Warncke, Chr., skoleinspektør,

Nordborg

Wolff, lærer, Nordborg

Notmark sogn:

Andresen, Andreas, lærer, Fynshav

Biblioteket, Notmark

Bromand, Jørgen, gårdejer, Almsted

Jespersen, Nicolaj, sogneråds-

formand, Notmark

Paulsen, Hans, forpagter, Smørholm

Terkelsen, Frede, højskoleforstander.

Danebod

Thomsen, Hans, gårdejer, Bommerlund

Nybøl sogn:

Ludvigsen, Valdemar, sognefoged, Nybel

Oksbøl sogn:

Alshauge, sognepræst, Oksbøl

Jørgensen, Jakob, gårdejer, Brandsbal

Schmidt, Mads, gårdejer, Brandsbøl

Schmidt, Nis, gårdejer, Brandsbøl

Schmidt, Nis V., gårdejer, Broballe

Sottrup sogn:

Alexandersen, Kata, fru, V.Sottrup

Andersen, C. J., førstelærer, V. Sottrup

Biblioteket, Snogbæk

Bonefeld, Olav J,, gårdejer, Snogbæk

Clausen, P., gårdejer, Lundsgårdmark Hansen, Peter, læge, V. Sottrup 
Hanssen, Sv. A., gårdejer, Nørremølle

Iversen, H., gårdejer, Gronvang

Jørgensen, Hans, kommunesekretær, V. Sottrup

Knudsen, Erik, konsulent, V. Sottrup

Moller, Jens, rentier, V. Sottrup

Nielsen, Chr., konsulent, V. Sottrup

Nissen, Jeppe, købmand, V. Sottrup

Petersen, Peter A., kontorist, V. Sottrup

Paulsen, T. R., stationsmester, V. Sottrup

Sottrup sogneråd, V. Sottrup

Thordsen, Hans Th., frisør, V. Sottrup

Svenstrup sogn:

Skov, Olav, højskoleforstander, Svenstrup

Sognebiblioteket, Svenstrup

Tandslet sogn:

Bill, Laue, bager, Nd. Tandslet

Petersen, F. C., lærer, Tandslet

Roesdal, H., læge, Tandslet

Ulkebal sogn:

Biblioteket, Ulkebøl

Hansen, Martin, sognepræst, Ulkebøl

Krogh, Jørgen, repræsentant, Langdel

Poulsen, Poul S., førstelærer, Skovhuse

Thomsen, Anne, lærerinde, Ulkebøl

Ullerup sogn:

Biblioteket, Ullerup

Warncke, sognepræst, Ullerup

\section{Tonder amt}

Tonder by:

Andersen, Knud, fhv. kordegn

Andersen, Poul, kørelærer

Andersen, J. Rahbek, gårdejer,

Mejerholm

Andresen, A., amtslandmáler

Biblioteket

Brahm, Erling, skoleinspektør

Brejl, S. C. amtsskolekonsulent

Brenner, Fr., læge, dr. med.
Bødker, overfendrik

Bøving, Erik P., politimester

Christensen, Ehm, købmand

Christiansen, V., bogholder

Christiansen, $W$., viceskoleinspektor

Clausen, M. J., amtmand

Enemark, Inger, seminarielærerinde

Eskildsen, fru

Fabricius, Peter, materialhandler

Fanø, Knud, adjunkt

Frederiksen, Vilh., lærer

Hansen, Hans J., landsretssagfører

Hansen, E. Søndergaard, lærer

Hansen, Frede, seminarielærer

Helkiær, Otto, viceskoleinspektør

Henrichsen, I. M. H., adjunkt, frk.

Henriksen, $\mathrm{Kr}_{\text {., ingeniør }}$

Hinrichsen, P., direktør

Ingwersen, W., malermester

Jacobsen, Ingeborg, broderihandler

Jacobsen, T. Q., civilingenier

Jefsen, J. N. boghandler

Jensen Hans, bankfuldmægtig

Jensen, Jes, bogholder

Jensen, M., amtsfuldmægtig

Jensen, Niels, sekretær

Jensen, O., ingeniør

Jepsen, Peter, stabslæge, dr. med.

Jørgensen, A. Feilberg, rektor

Kiil-Nielsen, $\mathrm{Kr}_{\text {., }}$ overlæge

Kiilerich-Hansen, J., landsretssagfører

Knudsen, $H$. Munch, bankbogholder

Kristensen, K. P. konsulent

Larsen, Poul, lærer

Laursen, Christine, fru

Lytzen, Kirstine, overlærer

Lykkegaard, Aage, premierløjtnant

Magle, Hans, sognepræst

Mathiasen, Kathr., lærerinde

Matthiesen, Lisbeth, lærerinde

Moltke, Helene, viceskoleinspektør

Møller, Iver, politifuldmægtig

Nyholm, Asger, seminarieforstander, dr. theol.

Oudrup, Vagn, lærer

Paulsen, J., bankdirektør, borgmester 
Petersen, Chr., mejeriejer

Petersen, Henrik, landmand, Toft

Petersen, Johannes, købmand

Petersen, Johannes, skoleinspektør

Petersen, Jørgen Schiøler, landbrugskandidat

Petersen, P. J. arkitekt

Petersen, Thorvald, bagermester

Schmidt, Johs. Paulsen, boghandler

Schoubye, Sigurd, seminarielærer

Sieverts, Kaj, lektor

Skodborg, Christian, arkitekt

Statsseminariets bibliotek

Statsskolens bibliotek

Steenholdt, Jens, direktor

Stegmann, H. H., fhv. dommer

Svendsen, Nicolai, fhv, amtsskolekonsulent

Sørensen, Edv., redaktør

Tarp-Hansen, Gerda, overbibliotekar

Thygesen, Kristian, lærer

Toft, Aage, organist

Toft, Helene, fru

Tønder amtsstidende

Vestslesvigsk tidende

Westh, Thorkild Claudi, civilingenior

Abild sogn:

Andersen, Hans, gårdejer, Kongsbjerg

Arrild sogn:

Biblioteket, Arrild

Evald, P. Rostgaard, gårdejer, Roost

Madsen, Jeppe, gårdejer, Roostgård Thomsen, Hans, gårdejer, Roost

\section{Ballum sogn:}

Beier, N., gårdejer, fru, Assgård, Skast

Biblioteket, Ballum

Jensen, Ingvert, gårdejer, Husum

Lorenzen, Hans, gårdejer, Ballum

Nicolajsen, Fred., sognepræst, Ballum

Nielsen, Jørgen, lærer, Skast

Præstiin, H., lærer, Bodsbøl

Brede sogn:

Andresen, Holger, lærer, Harris

Biblioteket, Bredebro
Dahlmann, Niels, gårdejer, Storde

Gantzel, Enne Madsen, købmand, Bredebro

Holdt, J., provst, dr. theol., Bredebro

Moos, Peder, snedker, Bredebro

Nissen, Søren, gårdejer, Harris

Brons sogn:

Andersen, P. Obeling, Virkelyst, Brons

Biblioteket, Brøns

Historisk Samfund for Brøns sogn

Jacobsen, Aage, mølleejer, Brøns Mølle

Lodbjerg, Chr, fhv. førstelærer, Brøns

Malling, Anders, sognepræst, Brøns

Burkal sogn:

Andresen, A., dyrlæge, Bylderup Bov

Biblioteket, Rends

Damm, I., førstelærer, Burkal

Heick, Frederik, forsøgsleder, folketingsmand, St. Jyndevad

Jessen, Karl, lærer, Burkal

Karkov, A., lærer, Lund

Leick, Willy, førstelærer, Lydersholm

Spandet, N. C., førstelærer, St. Jyndevad

Tingleff, Jørgen, gårdejer, sognerådsform., Lund

Bylderup sogn:

Detlefsen, Hans M., sognepræst, Bylderup

Hedager, P., førstelærer, Bylderup

Jepsen, Chr., gartner, Bylderup-Bov

Knudsen, Nis, lærer, Bylderup

Pallesen, Erling, lærer, Bylderup

Destrup sogn:

Biblioteket, Døstrup

Ebbesen, Hans, sognepræst, Døstrup

Nielsen, Aage H., lærer, Drengsted

Nissen, Antion, førstelærer, Lovrup

Rattenborg, August, forstelærer, Destrup

Schmidt, Cornelius, gårdejer, Døstrup 
Emmerlev sogn:

Eriksen, Laust N., gårdejer,

S. Sejerslev

Lagoni, P. H., førstelærer,

S. Sejerslev

Larsen, L. A., førstelærer, Emmerlev

Laursen, C. J., førstelærer, Nr. Sejerslev

Lund, A. P., gårdejer, Byvang

Lund, Anders P., gårdejer, Emmerlev Klev

Hjerpsted sogn:

Brodersen, C., bagermester, Hjerpsted

Christiansen, J., købmand, Hjerpsted

Hostrup sogn:

Biblioteket, Jejsing

Christensen, Chr., vejformand, Jejsing

Jepsen, Mathias, gårdejer, Jejsing

Maibøll, C., pens. lærer, Jejsing

Matthiesen, Esben, førstelærer, Jejsing

Michelsen, Nikolai, landmand, Jejsing

Petersen, Hans, sognepræst, Hostrup

Petersen, Nis, gårdejer, Rørkær

Hviding sogn:

Gotthardsen, Niels, sekretær, Hogsbro

Hviding sogneråd

Jefsen-Christensen, $H$, fhv. landstingsmand, Hogsbro

Madsen, M., førstelærer, Hviding

Warming, M., gårdejer, Råhede

Hojer flække:

Barfod, Mogens, sognepræst, Højer

Biblioteket, Højer

Christensen, C. J., cand. pharm., Højer

Christiansen, Folmer, førstelæerer, Højer

Danielsen, Ingrid, lærerinde, Højer Hansen, Jens Mollerup, Iærer, Højer Mathiasen, Vilh., direktør, Højer
Hojer landsogn:

Kristensen, Iver, landmand, Rudbølgård

Stendevad, Johan, lærer, Rudbøl

Hojrup sogn:

Biblioteket, Arnum

Paulsen, Nic., sognepræst, Højrup

Højst sogn:

Biblioteket, Oster Højst

Hansen, Johs., købmand, Ellehus

Iversen, Aksel, gårdejer, Øster Højst

Thygesen, Hans, landmand, Adrelvad

\section{Løgumkloster flække:}

Beier, Morten, Logumkloster

Biblioteket, Løgumkloster

Blaabjerg, Vagn, kontorassistent, Løgumkloster

Bork Hansen, sognepræst, Løgumkloster

Kjems, J., apoteker, Løgumkloster

Thomsen, P. P., kæmner, Løgumkloster

Mjolden sogn:

Biblioteket, Mjolden

Helms, H. J., sognepræst, Mjolden

Møgeltønder sogn:

Biblioteket, Møgeltønder

Boyschau, Chr., gårdejer, Toghale

Clausen, J., førstelærer, Møgeltønder

Filskov, K., købmand, Møgeltønder

Linnet, Hans, forpagter, Møgeltønder

Nielsen, N. Juhl, lærer, Møgeltønder

Nissen, Theodor, kirketjener, Møgeltønder

Reggelsen, Chr., gårdejer, Toghale

Schack, Karin, lensgrevinde, Møgeltønder

Thomsen, Jens Chr., mejeribestyrer, Møgeltønder

Nr. Løgum sogn:

Biblioteket, Nr. Løgum

Friis, Claus J, gårdejer, Løgumgård

Pahus, Holger, sognepraest,

Nr. Løgum

Poulsen, Jens Refslund, lærer, Ny Bjerndrup 
Rabsted sogn:

Andersen, Frede, gårdejer, Knivsig

Biblioteket, Rabsted

Christensen, Sigfred, førstelærer, Rabsted

Gad, P. J., gårdejer, Rabsted

Iversen, Meta, lærerinde, Rabsted

Levinsen, S. M., politiassistent, Rabsted

Rejsby sogn:

Jensen, Truels, gårdejer, Rejsby

Roager sogn:

Biblioteksforeningen, Roager

Gad, Uffe K., gårdejer, Ravnholt

Pedersen, N. P. H., lærer, Roager

Rømø sogn:

Biblioteket, Rømø

Christensen, Anne, fru, Mølby

Skærbæk sogn:

Andersen, H. C., installatør,

Skærbæk

Beck, E., læge, Skærbæk

Biblioteket, Skærbæk

Fromsejer, skovrider, Skærbæk

Hamann, F. H., Skærbæk

Hansen, H. P., gæstgiver, Melby Kro, Skærbæk

Ipland, Joh., bankbestyrer, Skærbæk

Oksen, P., direktør, Skærbæk

Pedersen, Schack, uddeler, Skærbæk

Skærbæk kommune

Svendsen, Th., gårdejer, Hjemsted Ulfbeck-Petersen, E., læge, Skærbæk

Spandet sogn:

Smidt, Peter, gårdejer, Spandetgård

Tinglev sogn:

Alnor, læge, dr. med., Tinglev

Andersen, Chr., lærer, Tinglev

Biblioteket, Tinglev

Damgaard, P., gårdejer, Rødebæk

Fink, Gudmund, gårdejer, Stoltelund

Koopmann, Paul, dr. phil., forstander, Tinglev

Nielsen, Harald, postmester, Tinglev

Schmidt, Laur., lærer, Bajstrup

Tinglev sogneråd
Visby sogn:

Hansen, Th., branddirektør, Visby

Hinrichsen, Hans, forpagter,

Trøjborg

Schmidt-Nielsen, Knud, lærer, Visby

Sognebogsamlingen, Visby

\section{Sydslesvig}

Ejdersted kreds:

Bruhn, H. H., lærer, Tønning

Kølvraa, Anders, skoleleder,

Tonning

Møller, Flemming, præst, Tønning

Petersen, Hans, lærer, Tønning

Schöler, Anker, skoleleder, Garding

Flensborg by:

Andersen, Karen, cand. mag., Flensborg

Bille, N. J., lærer, Flensborg

Christensen, Helmuth, dr. jur.,

Flensborg

Christensen, L. P., redaktør, Flensborg

Duborgskolen, Flensborg

Flensborghus bogsamling, Flensborg

Friis, Louise, oversygeplejerske,

Flensborg

Fuglsang-Damgaard, præst, Flensborg

Glahn, T., overbibliotekar, Flensborg

Gudnæs, Bodil, cand. mag., Flensborg

Hansen, Karen, bibliotekar, Flensborg

Hansen, Richard Stig, adjunkt, Flensborg

Hersbøl, pens, stationsforstander, Flensborg

Houbak, P., lærer, Flensborg

Ipsen, Moldt, lærer, Flensborg

Isselhorst, Carla, dr. phil. Flensborg

Jacobsen, Westergaard, provst,

Flensborg

Jensen, Børge Herlin, lærer, Flensborg

Jepsen, Annette, lærerinde, Flensborg

Jessen, Marie, fru, Flensborg 
Tage Jessen, redaktør, Flensborg Jørgensen, Hans Ronald, boghandler, Flensborg

Jørgensen, Poul, præst, Flensborg

Madsen, Th., adjunkt, Flensborg

Matthiesen, Erik, forretningsfører, Flensborg

Mortensen, Martin, skoleinspektør, Flensborg

Nørgaard, Martin, præst, Flensborg

Olesen, Ejnar, viceskoleinspektør, Flensborg

Petersen, A., provst, Flensborg

Petersen, Ewald, fuldmægtig, Flensborg

Petersen, Signe, lærerinde, Flensborg

Poulsen, Hans, grosserer, Flensborg

Rattenborg, Karen, bibliotekar, Flensborg

Rattenborg, Marie Helene, Flensborg

Ruge, Chr., lærer, Flensborg

Schack, Erik, greve, generalkonsul, Flensborg

Stenz, Chr., viceskoleinspektør, Flensborg

Svensson, Poul, lærer, Flensborg

Thyssen, A. Pontoppidan, præst, Flensborg

Flensborg kreds:

Andresen, Karl, lærer, Vanderup

Büchert, Nicolai, lærer, Husby, Angel

Fink, Johs., lærer, Valsbøl

Gotthardsen, Michelle, skoleleder frk., Møllebro

Jensen, Kvist, præst, Valsbøl

Karstoft, Chr., præst, Jerrishøj pr. Tarp

Knudsen, Erik H., præst, Lyksborg Kjems, Niels, vandrelærer, Harreslev Krebs-Lange, Børge, førstelærer, Tarup

Kristensen, Knud, lærer, Sørup

\section{Husum kreds:}

Carstens, advokat, dr. jur., Husum Heinsen, Helge, præst, Husum
Schubert, Lars, amtssekretær, Husum

Rensborg kreds:

Achelis, Th. Otto, dr. phil., Rendsborg

Hansen, Andreas, lærer, Vestermolle, Rendsborg

Svendsen, Jens, præst, Rendsborg

Slesvig kreds:

Borg, Christa, lærerinde, Sdr. Brarup

Bundgaard, N., præst, Slesvig

Buur, Ove, præst, Sdr. Brarup

Heimann, Heinz, husejer, Arnæs

Holdt, Johannes, lærer, Satrup,

Angel

Jonasson, Hans E., lærer, Damholm

Jørgensen, Jørgen, vandrelærer, Slesvig

Kürstein, Poul, bibliotekar, Slesvig

Lund, Carl, lærer, Mårkær Vesterskov

Lüddens, Wilhelm, lærer, Satrup, Angel

Madsen, Hans, præst, Arnæs

Madsen, la Cour, ungdomskonsulent, Christianslyst pr. Sdr. Brarup

Pedersen, P. Storgaard, lærer," Hostrup pr. Havetoft

Petersen, Hans Fr., præst, Satrup, Angel

Rommerdahl, præst, Slesvig

Thade-Petersen, Alfhild, lærerinde, Slesvig

Vigh-Petersen, P., præst, Kappel

Wehlitz, Gerhard, lærer, Isted

Willumsen, A., lærer, Stenfeldt pr. Sdr. Brarup

Wittmaack, Anne Marie, lærerinde, Stenfeldt pr. Sdr. Brarup

Sydtonder kreds:

Boysen-Møller, præst, Nibøl

Dam, C. W., præst, Læk

Hansen, Dinsen, skoleinspektør, Nibøl

Hou, Arne, lærer, Humtrup

Jensen, Emil, lærer, Nykirke

Jensen, Tove Harritsø, lærerinde, Sild

Kristensen, Jørgen, præst, Aventoft 
Kristensen, Sig, skoleleder, Læk

Larsen, N. M., præst, Vesterland, Sild

Lindstrøm, Gustav, vandrelærer, Ladelund

Nielsen, Anton, lærer, Sild

Schrøder, Anna, lærerinde, Aventoft

\section{Stor-København}

Adolph, Andreas, kommunelærer, Markmandsg. 14, 4, S

Andersen, Elius, vinhandler, Østerbrog. $46, \varnothing$

Andersen, Emilie, arkivar v. landsarkivet, Vikkevangen 6, Brh.

Andersen, Holger, præsident, Duntzfeldsalle 26, Hellerup

Andersen, J. Oskar, professor, Ratzaksvej 5, V

Andreasen, Øjvind, cand. mag., Fiolstr. 14², K

Aug. Olsens boghandel, Strandvej 189, Hellerup

Bendix, Adam B., direktør, Helleruplundalle 7, Hellerup

Bing, Gerda, fru, Sveasvej 7, V

Biblioteket, Vester Borgerdydsskolen, Helgolandsg., 6, V

Bjerrum, Anders, dr. phil., Skovgårdsv. 8, Charl.

Boesen, Gudmund, museumsinspektør, Rosenborg, $\mathrm{K}$

Bracher, Willy B., overlærer, Fennevangen 26, Gentofte

Christensen, Balthazar, dommer, Emiliekildevej 13, Klampenborg

Christensen, E. P., kommunelærer, Veronavej 16, $S$

Clausen, Karl, lektor, Godthåbsvej $77, \mathbf{F}$

Dahl, Ellen, fru, Sølvgade 26, K

Dahl, Sven, rigsbibliotekar, Hostrups Have 271, F

Dalgaard, Sune, arkivar, Hans Tavsensgade $1, N$

Dalgaard, K., kommunelærer, Drosselvej 20, F
Dansk Folkemindesamling, Det kgl. Bibliotek, K

Dein, Anton, lektor, Ejderstedgade 14, $\mathrm{V}$

Due, Gudrun Bossen, frk. Nøragervej 14, Vanløse

Eller, Povl, cand maig., Parmagade $40^{3}, \mathrm{~S}$

Eriksen, C. E., viceskoleinspektør, Peblingedoss. $32^{3}$, N

Folketingets Bibliotek, Christiansborg, $\mathrm{K}$

Frederiksen, F. C., ing., Grondals Parkv. 108, Vanløse

Friisager, salgschef, Bredalsvej 14, Valby

Fræmohs, A., kontorchef, Ellinorsvej 24, Charl.

Gangsted, Erik, landsretssagfører, St. Strandstr. 21, K

Grænseforeningen, Peder Skramsgade $5^{1}, \mathrm{~K}$

Hammer, Agnete, Vennemindevej $39, \varnothing$

Hansen, E. Hart, overlæge, dr. med., Ellehøj 11, Hellerup

Hansen, Magnus, grosserer, Landemærket $43, \mathrm{~K}$

Hansen, Paul Erik, magister, TrapsAlle 1, Valby

Hansen, Sigrid, kommunelærerinde. Vadstrupvej 53, Bagsværd

Harbo, Jørgen, præst, Sortedamsdossering 45, N

Arvingerne eft. afd. rektor P. M. Hertz, Slotsv, 35, Charl.

Hjelholt, Holger, overarkivar, dr. phil., Markvej 15, F

Horsten, Holger, kontorchef, Dyrehavevej 6, Klampenborg

Hulegaard, Axel, overretssagf., Bjerregårds Sidev. 4, Valby

Hvid, M., politiskolechef, Artillerivej $53, \mathrm{~S}$

Hyllingsted, J., Kastrupvej 62 ${ }^{2}$ S .versen, $M_{\text {., dr }}$ polit., Oldfuxvej 14, NV 
Jacobsen, N. Kingo, cand. mag., $\varnothing$ sterbrog. $91^{1}, \varnothing$

Japsen, G., redaktionssekretær, Vadbro 46, Søborg

Jensen, M. Kürstein, kontorchef, Fragariavej 4, Hellerup

Jepsen, Ove, Nationalbankdir., Sortedamsdossering $69, \varnothing$

Jessen, Knud, prof. dr. phil., Gothersg. 140, K

Jones, Mary, fru, Østerbrogade 872, $\varnothing$

Jørgensen, H. N. cand. mag., Vibevej $73 \mathrm{NV}$

Jørgensen, Jørgen, maskinfabrikant, Prags Boulevard 56, S

Jørgensen, Peter, prof. dr. phil. Jydeholmen 42, Vanlose

Kalum, H. Holt, kontorchef, Anemonevej 7, Gentofte

Kiil, J. H. kontorchef, Kochsvej $4^{2}$, $\mathrm{V}$

Kirchhoff, Johs. kgl. aut. translatør, Alekistev. $49 \mathrm{~b}^{2}$, Vanløse

Kjøgx, Kai, sekretær, St. Kjeldsplads $1^{4}, \varnothing$

Klint, Jon, kommunelærer, Mariendalsvej 75, F

Koch, Hal, prof. dr. theol., Malmøgade $6, \varnothing$

Kommunebiblioteket, Hvidovre, Valby

Kretschmer, Mogens, sagfører, Gl. Strand 40, K

Kristensen, Edith, fru, Nordre Alle 16, Valby

Kurtzweil, $P_{\text {, }}$ revisor, Gustav Adolfsgade $4^{2}, \varnothing$

Kyllesbech, L., sagførerfuldm., Hartmannsvej 17. Hellerup

Lading, Henry P., direktar Viggo Rothesvej 7, Charl.,

Landsarkivet, Jagtvej 10, N

Larsen, Poul, statsaut. translatør, Voldgărden $2^{3}, \mathrm{~K}$

Lebeck, Margr., enkefru, Sortedamsdossering $95 \mathrm{~B}, \varnothing$
Linwald, Axel, rigsarkivar, Norgesmindevej 20, Hellerup

Louw, A. Charles, adm. direktør, Gl. Kongevej $1 \mathrm{~F}, \mathrm{~V}$

Lund, Søren, instrumentmager, Siciliensgade $6^{4}, \mathrm{~S}$

Lützhøft, H., civilingeniør, Rådhusplads $45, \mathrm{~V}$

Lænkholm, Kai, sognepræst, Ole Borchsvej 15, Valby

Mackeprang, M., dr. phil, fhv. museumdir. Odruphøjvej 40, Charl.

Madsen, C. L., vicefæengselsinsp. V. Kirkegårdsalle 1, SV

Madsen, Haakon B., Offenbachsvej 8, SV

Marstrand, Vilh., ingeniør, Øster Voldgade $10 \mathrm{~N}, \mathrm{~K}$

Møller, Valentin Aage og Co., Dr. Tværgade 5, K

Moltke, Carl, generalmajor, Maglevænget 8, Charl.

Mølholm, Klavs, prokurist, Tåsingegade $2^{3}, \varnothing$

Nationalmuseets II afdeling, $K$

Nationalmuseets III afdeling, Frederiksholms Kanal 12, $\mathrm{K}$

Nielsen, Herluf, cand. mag., Norasvej 32, Charl.

Nielsen, Vald. Valgmenighedspræst, Julius Thomsens Plads $\mathbf{2}^{\mathbf{1}}, \mathrm{V}$

Nissen, Harald, civilingeniør, Moltkesvej 20, F

Nordlien, P., fru, Puggårdsgade 14, V

Nerregaard, Georg, dr. phil., H. C. Andersensgade 10, K

Petersen, Carl S., fhv. overbibliotekar, Solvej 2, F

Plum, Inger Marie, frk., Vestre Boulevard $51, \mathrm{~V}$

Prieme, Ruth, fru, Emnanuel Olsensvej $6, F$

Rasmussen, Willy, adjunkt, Palnatokesgade $3^{4}, \mathrm{~V}$

Rasmussen, W. S., afdelingschef, Gyldenløvesgade $10, \mathrm{~K}$

Rigelsen, Jens manufakturhdl., Frihedsvej 7, F 
Rigsarkivet, $\mathbf{K}$

Rolvsen, Stig, stud. mag., Sdr. Fasanvej 52, Valby

Roos, Carl, prof. dr. phil., Sylowsalle 19, F

Rud, Chr., læge, Kameliavej 7, Hellerup

Rudbeck, H. N., overlærer, Strandboulevard $117^{3}, \varnothing$

Schinager, F. W. H., elektroinst. Vesterbrogade $96^{4}, \mathrm{~V}$

Seidenfaden, fhv. politidir., Strandvejen 219, Charl.

Simonsen, Chr., postassistent, Brunevang 53', Brh.

Skadhauge, antikvarboghandler, Nr. Voldgade 102, K

Smidt, Jonathan, fhv. amtsassesor, Ågade 98: $\mathrm{N}$

Sommer, Otto, Vilh., antikvarboghandler, Tranegårdsvej 50", Hellerup

Spang-Hansen, E., kontorchef, Banevej 11, Charl.

Statens Museum for Kunst, Sølvgade, $K$

Steenbeck, L. A. papirhandler, Hvælvingen, $K$

Sønderjydsk Forening for Gentofte kommune, Charl.

Sønderjydsk Forening for København, Rådhuspladsen $45, \mathrm{~V}$

Thaulow, Per, politifuldmægtig, Esplanaden 46, K

Thaysen, Holger, apoteker, Gustav Adolfsgade 5, $\varnothing$

Tholle, Johs., havearkitekt, Laur. Sørensensvej 2, F

Thorsen, Svend, protokolsekretær, Peter Bangsvej 209, Valby

Thuesen, Gunnar, grosserer, Østerled $3, \varnothing$

Udenrigsministeriets Bibliotek, $\mathbf{K}$

\section{Det øvrige Danmark}

Aaholm, Th., pastor emer., Roskilde

Andersen, Jørgen, lektor, Herlufsholm
Andersen, Vald., lærer, Bække Andrup, Birthe, bibliotekar, Odense Appel, Erik, magister, Skibelund Arnfred, J. Fr., forstander, Askov Bak, Jens, stadsskoleinspektør, Gl. Lindholm Skole pr. Nr. Sundby

Bang, G. C., overtoldassistent, Silkeborg

Bernt-Andersen, H. C., dommerfuldmægtig, Løgstør

Biblioteket, Askov Højskole

Biblioteket, Esbjerg

Biblioteket, Finderup, Høng

Biblioteket, Fredericia

Biblioteket, Helsingør

Biblioteket, Herning

Biblioteket, Hillerød

Biblioteket, Holstebro

Biblioteket, Kolding

Biblioteket, Krogerup Højskole, Humlebæk

Biblioteket, Køge

Biblioteket, Lyngby

Biblioteket, Nyborg

Biblioteket, Nykabing $M$.

Biblioteket, Odense

Biblioteket, Randers

Biblioteket, Ribe

Biblioteket, Roskilde

Biblioteket, Silkeborg

Biblioteket, Skern

Biblioteket, Skive

Biblioteket, Slagelse

Biblioteket, Thisted

Biblioteket, Vejen

Biblioteket, Vejle

Biblioteket, Viborg

Bock, Karl N., rektor dr. phil., Nakskov

Bolding, Ruth, lærerinde, Fredericia

Bonde, Aage, bibliotekar, Arhus

Brummer, Knud, Lundsminde, Taps

Brøndsted, Sigurd, højskoleforstander, Velling

Bøggild-Andersen, Carl O., prof. dr. phil., Arhus

Bønnerup, Anne Marie, lærerinde, Haslev 
Centralbiblioteket, Århus

Christensen, Arthur, fru, Kg. Lyngby

Christensen, C. A., mag. art., Holte

Christensen, O. Elmkvist, postbud, Frederikshavn

Clausen, H. P., cand. mag., Institutet for nyere Historie, Århus Universitet

Dahl, Aage, præst, Horsens

Damgaard, sundhedsplejerske, fru, Roskilde

Det nordjyske Landsbibliotek, Ålborg

Dickmeiss, P., overlæge, Dianalund

Enevoldsen, lærer, Herringe skole, Rudme

Erhvervsarkivet, Århus

Fabricius, R., divisionschef, Gilleleje

Faurbye, Arild, afdelingslæge, dr. med., Roskilde

Fink, Ernst, højskoleforstander, Høng

Fink, Poul, politifuldm., Ringkøbing

Fink, Troels, prof. dr. phil., Århus

Fredslund, Ragna, Ejstrup

Frølund, Erik, civilingeniør, Køge

Fyens Stifts Laseforening, Odense

Føge-Jensen, Johan, fabrikant, Sorgenfri

Glaven, P., læge, Pedersker

Graugaard, Erik, stud. med., Århus

Gregersen, Hans V., adjunkt, Struer

Hansen, C. Rise, arkivar, Roskilde

Hansen, Chr. R., lærer, Øster Vedsted

Hansen, Engers, boghandel, Esbjerg

Hansen, Ocke, sekretær, Roskilde

Hansen, Sigurd Brandt, friskolelærer, Lunde

Hasselbalch, K. A., Dr. med, Snekkersten

Hatting, Jørgen, lektor, Rungsted

Helsingør Gymnasium

Henriksen, Svend H., lærer, Odense

Hvidtfeldt, Erik, købmand, Vejle

Hvidtfeldt, Joh., landsarkivar, Viborg

Høeg, J. C., læge, Herning

Høfring, P., sognepræst, Sundby
Ingvorsen, Leif, seminarielærer, cand. mag., Gjedved

Jensen, Johs., friskolelærer, Ollerup

Jensen, P., Feddersen, pens. lærer, Outrup

Jensen, Poul Vagn, civilingeniør, Nyborg

Jeppesen, P., lektor, Århus

Jepsen, J. Kr., arkitekt, Kolding

Jessen, Jørgen, højskoleforstander, Vallekilde

Johannsen, H. P., førstelærer, Losning st.

Juhl, F., dommer, Nørre Sundby

Jørgensen, Harald, arkivar dr. phil., Humlebæk

Karberg, A. V., fhv. amtmand, dr. jur., Rindum

Karkov, A., lektor, Maribo

Killemose, højskolelærer, Vallekilde

Kjær, Aage, politifuldmægtig, Alborg

Kolster, Jan Preben, læge, Stovring Kondrup, Beth, sekretær, cand. jur., Kgs. Lyngby

Kragh-Petersen, apoteket, Odense

Kretschmer, Knud, lektor, Lyngby

Krogh, Anna, forstanderinde, Snoghøj

Ladegaard, T. K., konsulent, Næsbystrand

Ladelund Landbrugs- og Mælkeriskoles Bibliotek, Brørup

Landsarkivet, Viborg

Langholz, C., bibliotekar, Viborg

Lassen, Harald, læge, Borris

Lassen, Johanne, sygeplejerske,

Borris

Lauritzen, L., Tylstrup Forsøgsstation

Lind, Chr., fabrikant, Herning

Lind, Hans, apoteker, Randers

Lindegaard, M. C., biskop, Ribe

Lorenzen, Christian, tandlæge, dr.

med. dent., Ribe

Lorenzen, H., cand. phil., Brædstrup

Ludvigsen, Chr., kontorchef, Holte

Lund, Hans, fhv. forstander,

Tanderupgård, Ribe 
Lunden, A. P., forpagter, Dyrehavegård, Kolding

Lunn, Knud, overlæge, Knabstrup

Løber, Kaj, rektor, Ålborg

Marcussen, P., lærer, Karlslunde

Martensen-Larsen, $T$., politimester, Odense

Matthesen, Math., sognepræst, Egense

Meyer-Heiselberg, R., cand. mag., Birkerød

Michaelsen, P., fru, Lunderskov

Mikkelsen, seminarielærer, cand. mag. Vordingborg

Møller, bager, Vejen

Møller, Jørgen Kisbye, landsdommer, Grønland

Møns Folkebibliotek, Stege

Nakskov kommunale Gymnasium, Nakskov

Nielsen, Axel V., cand. mag. Arhus

Nielsen, Ejnar, Nørager

Nielsen, Ely, overassistent, Ålborg

Nielsen, Gunhard, civildommer, Frederikssund

Nielsen, Jens H., lærer, Kerte

Nielsen, Johs. Birkedal, sognepræest, Vejle

Nielsen, P. Gamborg, forstander, Esbjerg

Nielsen, Viggo, ekspedient, Nykabing $F$.

Nyholm, Rigmor, overlærer, Ballerup

Nykøbing Katedralskoles Bibliotek, Nykøbing $F$

Olesen, N. C., Randers

Olesen, R. Bakkegaard, præst, Dannemare

Pape, C. J., salgschef, Fannerup pr. Kolind

Parmann, Hans, præst, Horsens

Paulsen, Jørgen, museumsdirektør, Hillerød

Pedersen, Dan, civilingeniør, Roskilde

Petersen, A. Brandt, forstander, Vrå st.
Petersen, C. M., sognepræst, Sdr. Stenderup

Petersen, Holger, ingeniør, Lyngby

Petersen, P. Jessen, dyrlæge, Bagsværd

Petersen, Poul grosserer, Allerød

Randløv-Jensen, P., lærer, Gudumlund

Randrup, J., fhv. rektor, Silkeborg

Rasmussen, Asger, dommer, Kolding

Rasmussen, K. A. Boje, forstander, Taulov

Ravn, J., overlærer, Bagsværd

Reiff, overlærer, Skårup

Ribe Katedralskole

Ruff, Marius Jørgensen, landmand, Sølvager

Rydal, Marie, fru, Ringe

Sarup, Kaj, redaktıonssekretær, Lyngby

Schmidt, Anders, afdelingslæge, Vodskov

Schwensen, Chr., civilingeniør, Trudsholm

Schütte, Gudmund, dr. phil., godsejer, Eskjær

Skautrup, Peter, professor dr. phil., Risskov

Skovmand, Holger, pens. skoleinspektør, Bagsværd

Sodborg, J. M., overlærer, Lemvig

Statsbiblioteket, Århus

Stiftsbiblioteket, Maribo

Stærmose, R., forstander, Norresundby

Svane, Jørgen, amtsforvalter, Vejle Svane, Jørgen, førstelærer, Vrigsted Søllerød Kommunebibliotek, Nærum Teilmann, Torkild, læge, Give Thomsen, Lars Boe, handelsrejsende.

Assens

Thorborg, redaktør, Korser

Thysen, Hans S., sognepræst, Ødis

Vejle Gymnasium

Wind, Jørgen, Lystrup

Wilson, E., lektor, Horsens 
Vollertsen, Ernst, seminarieelev,

Historisk Samfund for SonderjylRibe

Vyff, Kristian, proprietær, Vonsild st. land står i bytteforbindelse med ca. 50 foreninger og institutioner $i$ indog udland.

\section{Udlandet}

\section{Norge}

Simonsen, Poul, mag. art., Tromsø Museum, Tromsø 



$$
\text { - }
$$





\section{Skrifter, udgivne af Historisk samfund for Sønderjylland:}

Nr. 1. Erik Christensen: Fra min virksomhed i Tønder. 2,25 kr. (I boghandelen kr. 3,00).

Nr. 2. P. J. Refshauge: Bonden, der blev landråd. Udsolgt.

Nr. 3. Tønder gennem tideme. I--II. $25 \mathrm{kr}$. (I $14 \mathrm{kr}$., II $11 \mathrm{kr}$.). $(37,50)$.

Nr. 4. M. H. Nielsen: Tra slesvigsls fattigræsens fortid. $4,50 \mathrm{kr}$. $(6,00)$.

Nr. 5. Troels Fink og Johan Hvidtfeldt: Vejledning i studiel af Sonderjyllands historie. $4 \mathrm{kr} .(8,00)$.

Nr. 6. Navneregister til H. P. Hanssens verker. Udgivet af Johan Hvidtfeldt. $2 \mathrm{kr}$. (4.00).

Nr. 7. Aktstykker vedrorende Kreditanstalt Vogelgesangs tilblivelse. $3 \mathrm{kr}$. $(4,50)$.

Nr. 8. Peter $\mathrm{Kr}$. Iversen: Vejledning for sønderjyske lokalhistorikere. $2 \mathrm{kr}$. (3,00).

Nr. 9. Johan Hvidtfeldt: Slagtshistoriske studier i Sønderjylland. 2 kr. $(3,00)$.

Nr. 10. Nordslesvigs åndelige genforening med Danmark. $6 \mathrm{kr} .(10,00)$.

Nr. 11. Olav Christensen: Bibliografi over senderjydsk slagtstavlelitteratur. 2. kr. $(3,00)$.

Nr. 12. Nordslesvig efter genforeningen, 7 radioforedrag. $3 \mathrm{kr}$. $(4,50)$.

Nr. 13. Thorvald Petersen: Fra Ais til Tender. Uasolgt.

Nr. 14. N. Black Hansen: Ábenrå anncler, 1524, 1584--1694. $4 \mathrm{kr} .(6,00)$.

Nr. 15. Peter Kr. Iversen: Kniplingskræmmer Jens Wulffs dagbog. $12 \mathrm{kr} .(18 \mathrm{kr}$.)

Nr. 16. A. Svensson: Redaktør J. Jessen, Flensborg Avis, I. $10 \mathrm{kr} .(15 \mathrm{kr}$.) 


\section{Historisk samfund for Sønderjylland}

\section{udgiver Sønderjydske årbøger og Sønderjydsk månedsskrift.}

Styrelsen er for tiden fhv. amtslæge, dr. med. H. Lausten-Thomsen, Abenrå (formand), arkivar Peter Kr. Iversen, Ảbenrå (sekretær), fuldmægtig Olav Christensen, Haderslev (kasserer), som foreløbige amtsudvalgsformænd: sognepræst $H$. Hejselbjerg Paulsen, Fjelstrup, gårdejer Sv. Anker Hanssen, Nørremølle, gårdejer Cornelius Schmidt, Døstrup, jkoleinspekt $\emptyset r$ P. Clausen, Abenrå, pastor H. F. Petersen, Satrup, endvidere: viceskoleinspektør Werner Christiansen, Tønder, adjunkt Kinud Fan $\varnothing, T \varnothing n d e r$, professor, dr. phii. Troels Fink, Arhus, landsarkivar Johan Hvidtfeldt, Viborg, fhv. højskoleforstander Hans Lund, Tanderupgărd, museumsinspektør Hans IVeumann, Haderslev, viceskoleinspekt $\emptyset \mathbf{r}$ Chr. Stenz, Flensborg, og som æresmedlem fhv. museumsdirektør, dr. phil. M. Mackeprang, København.

Formand, sekretær og kasserer danner forretningsudvalg.

Redaktionsudvalget for Sønderjydske årbøger består af $\mathrm{H}$. LaustenThomsen, Johan Hividtfeldt, Peter $\mathrm{Kr}$. Iversen og Knud Fanø.

Redaktionsudvaget for Sønderjydsk måneasskrift består af Hans Neumann, Chr. Stenz og Werner Christiansen.

Skriftrækken redigeres af Troels Fink, Johan Hvidtfeldt, Hans Lund og Peter Kr. Iversen.

Medlemsbidraget er for tiden kr. 7,50 årl. + porto eller mindst 100 $\mathrm{kr}$. en gang for alle. Medlemmerne modtager Sønderjydske årbøger gratis. Sønderjydsk månedsskrift bestilles hos viceskoleinspektør W. Christiansen, T $\emptyset$ nder, og koster $3 \mathrm{kr}$. fjerdingårligt. Indmeldelser modtages af alle styrelsesmedlemmer

\section{INDHOLD:}

Han s V a ld. Gregerse n: Bonde og øvrighed i Åbenrå amt omkring år $1600 \ldots \ldots \ldots \ldots \ldots \ldots \ldots \ldots$ side $153-180$

H. F. P e terse n: Et billede fra sønderjydsk altergang o. 1650 .....................................

Peter Kr. I ve rs en: Kniplingskræmmer Jens Wulffs

Peter $K r$. I versen: Oversigt over afhandlinger vedrørende sønderjydsk historie i tyske tidsskrifter $1953-54$

$\Rightarrow 181-183$
$\Rightarrow \quad 184-227$

$\Rightarrow 228-248$
$\Rightarrow 249-269$
$>270-276$
$\Rightarrow 281-286$
$\Rightarrow 287-289$
$\Rightarrow 290-309$

I kommission hos

Danske Boghandleres Kommissionsanstalt, Nyropsgade 19, København V. 